\title{
A Summary of Coupled, Uncoupled, and Hybrid Tectonic Models for the Yakima Fold Belt
}

\section{Topical Report}

MA Chamness

$K$ Winsor

SD Unwin

August 2012

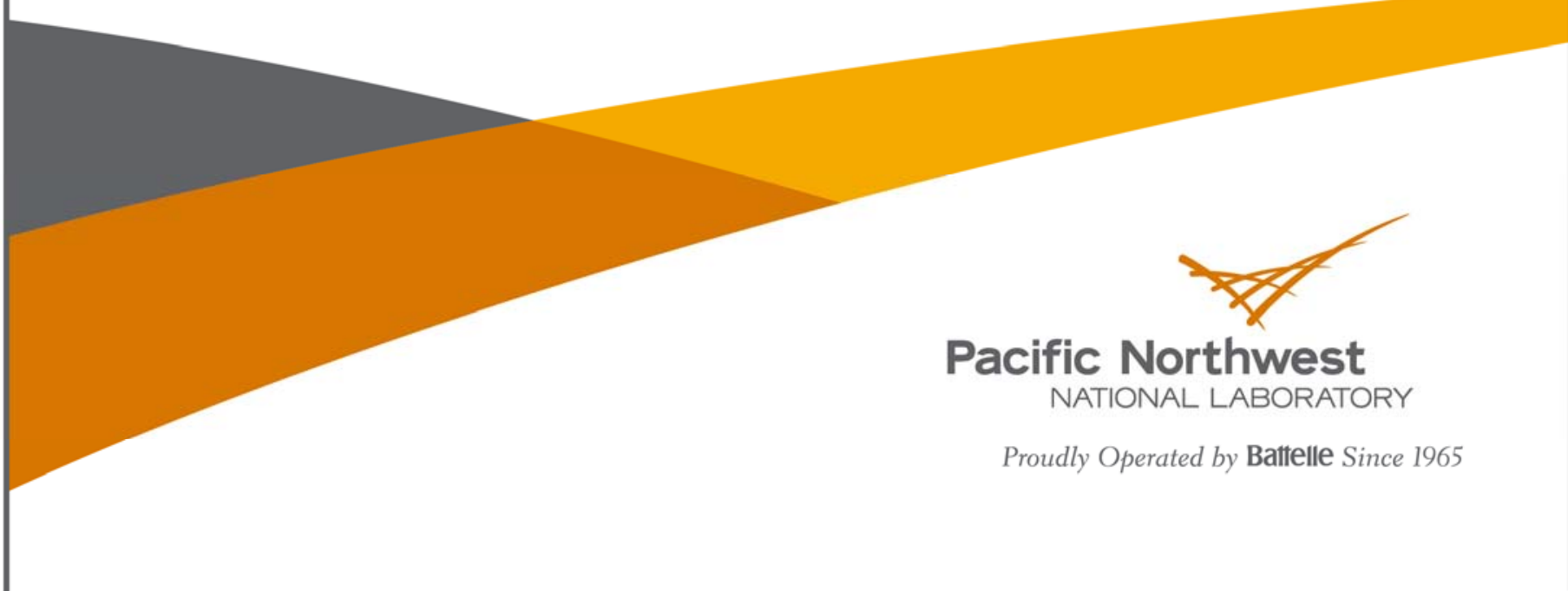




\title{
DISCLAIMER
}

This report was prepared as an account of work sponsored by an agency of the United States Government. Neither the United States Government nor any agency thereof, nor Battelle Memorial Institute, nor any of their employees, makes any warranty, express or implied, or assumes any legal liability or responsibility for the accuracy, completeness, or usefulness of any information, apparatus, product, or process disclosed, or represents that its use would not infringe privately owned rights. Reference herein to any specific commercial product, process, or service by trade name, trademark, manufacturer, or otherwise does not necessarily constitute or imply its endorsement, recommendation, or favoring by the United States Government or any agency thereof, or Battelle Memorial Institute. The views and opinions of authors expressed herein do not necessarily state or reflect those of the United States Government or any agency thereof.

\author{
PACIFIC NORTHWEST NATIONAL LABORATORY \\ operated by \\ BATTELLE \\ for the \\ UNITED STATES DEPARTMENT OF ENERGY \\ under Contract DE-AC05-76RL01830
}

Printed in the United States of America

$$
\begin{aligned}
& \text { Available to DOE and DOE contractors from the } \\
& \text { Office of Scientific and Technical Information, } \\
& \text { P.O. Box } 62 \text {, Oak Ridge, TN } 37831-0062 \text {; } \\
& \text { ph: }(865) 576-8401 \\
& \text { fax: (865) 576-5728 } \\
& \text { email: reports@adonis.osti.gov }
\end{aligned}
$$

Available to the public from the National Technical Information Service 5301 Shawnee Rd., Alexandria, VA 22312 ph: (800) 553-NTIS (6847)

email: orders $a$ ntis.gov $<$ http://www.ntis.gov/about/form.aspx $>$ Online ordering: http://www.ntis.gov 


\section{A Summary of Coupled, Uncoupled, and Hybrid Tectonic Models for the Yakima Fold Belt}

\section{Topical Report}

MA Chamness

K Winsor

SD Unwin

August 2012

Prepared for

the U.S. Department of Energy

under Contract DE-AC05-76RL01830

Pacific Northwest National Laboratory

Richland, Washington 99352 



\begin{abstract}
This document is one in a series of three topical reports compiled by the Pacific Northwest National Laboratory to summarize technical information on selected topics important to the performance of a probabilistic seismic hazard analysis of the Hanford Site. The data used to compile this report are based on studies and a literature search current through 2008.

The purpose of this report is to summarize the range of opinions and supporting information expressed by the expert community regarding whether a coupled or uncoupled model, or a combination of both, best represents structures in the Yakima Fold Belt. This issue was assessed to have a high level of contention and up to a moderate potential for impact on the hazard estimate.
\end{abstract}

This report defines the alternative conceptual models relevant to this technical issue and the arguments and data that support those models. It provides a brief description of the technical issue and principal uncertainties; a general overview on the nature of the technical issue, along with alternative conceptual models, supporting arguments and information, and uncertainties; and finally, suggests some possible approaches for reducing uncertainties regarding this issue. 



\section{Acronyms and Abbreviations}

ACM

CLEW

CRBG

GMA

Ma

NGA

OWL

PSHA

RAW

SSC

SSHAC

TI

TR

YFB

alternative conceptual model

Cle Elum-Wallula deformed zone

Columbia River Basalt Group

ground motion attenuation

mega-annum; millions of years before present

next generation attenuation (model)

Olympic-Wallowa lineament

probabilistic seismic hazard analysis

Rattlesnake-Wallula alignment

seismic source characterization

Senior Seismic Hazard Analysis Committee

technical integrator

topical report

Yakima Fold Belt 



\section{Glossary of Terms}

coupled model - The coupled model, sometimes referred to as the thick skin model, is one in which the faults coring the Yakima folds are rooted in the basement and extend through the sedimentary layer and into the basalts (Zachariasen et al. 2006), resulting in folding at the surface (Figure G.1).

uncoupled model - The uncoupled model, sometimes referred to as the thin skin model, is one in which faults coring the folds and faults in the basement are completely unconnected to each other structurally and seismically (Figure G.1). Faulting in the basalt does not extend into the basement and vice versa (Zachariasen et al. 2006).

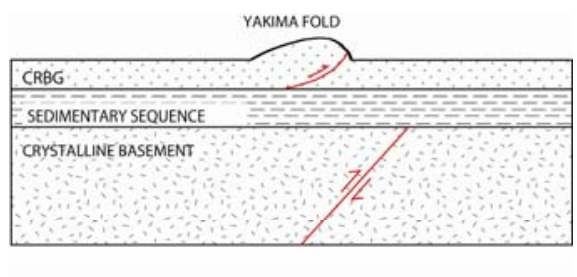

UNCOUPLED MODEI

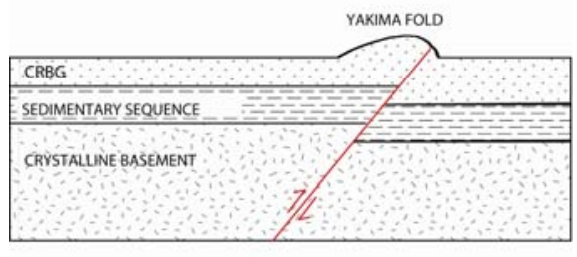

COUPLED MODEL

Figure G.1. Coupled Versus Uncoupled Tectonic Models (after Geomatrix 1996, Figure 2)

décollement - A décollement or detachment fault is a fault in which crustal deformation causes separation along a boundary between rock types, typically between crystalline rock and sedimentary rocks. The décollement horizon acts as a gliding plane between the two masses and often produces a situation where the rocks above the décollement have entirely different structures than the rocks below the fault. 



\section{Contents}

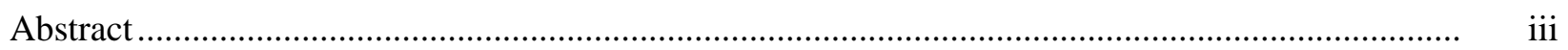

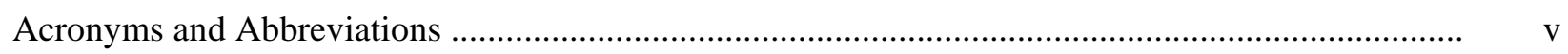

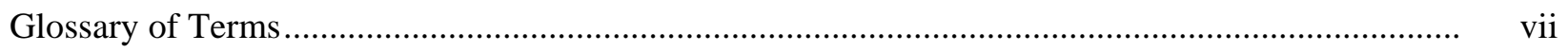

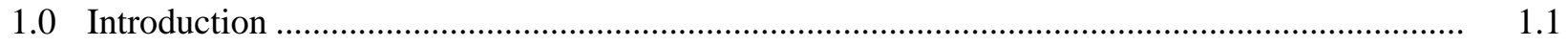

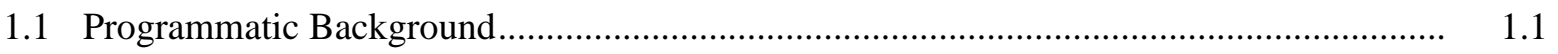

1.2 Selection of Topical Report Issues........................................................................... 1.2

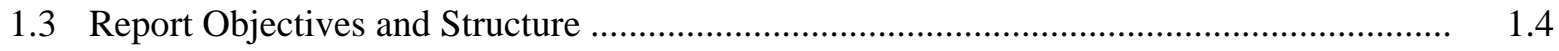

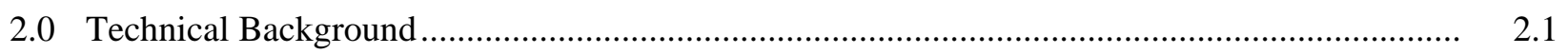

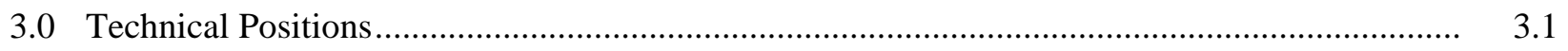

3.1 Alternative Conceptual Model 1 .............................................................................. 3.1

3.1.1 Mechanical Arguments ............................................................................... 3.2

3.1.2 Continuity of Structures Arguments.............................................................. 3.2

3.1.3 Geophysical Arguments ............................................................................... 3.4

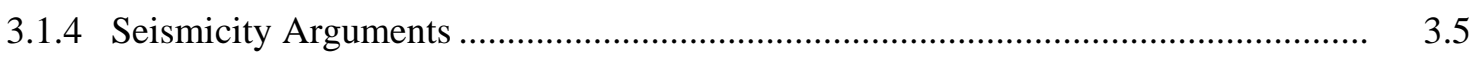

3.2 Alternative Conceptual Model 2 ............................................................................. 3.5

3.2.1 Mechanical Arguments ..................................................................................... 3.5

3.2.2 Continuity of Structures Arguments............................................................ 3.6

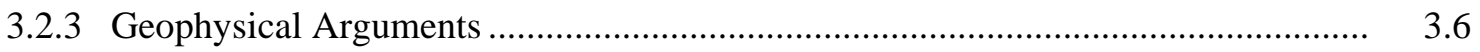

3.2.4 Seismicity Arguments ................................................................................... 3.7

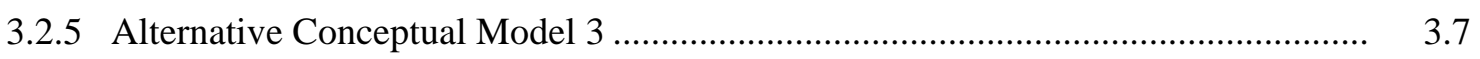

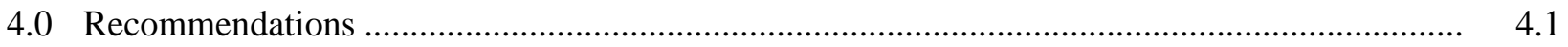

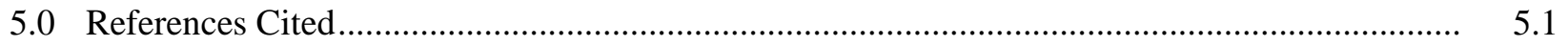

Appendix A - Identification of Topical Reports to Be Prepared for the Future

Hanford Site-Wide Probabilistic Seismic Hazard Analysis ................................................... A. A

Appendix B - Annotated Bibliography …....................................................................... B. 1

\section{Figures}

2.1 Coupled Versus Uncoupled Tectonic Models ..................................................................... 2.1

2.2 Major Structural Features in the Columbia Basin.............................................................. 2.2 



\subsection{Introduction}

This document is one in a series of three topical reports (TRs) compiled by the Pacific Northwest National Laboratory (PNNL). Based on scientific investigations and a literature search performed up to 2008, the TRs are intended as technical resources in the performance of a probabilistic seismic hazard analysis (PSHA) of the Hanford Site. This report discusses the scientific arguments regarding whether faults and folds in the Yakima Fold Belt (YFB) are coupled or uncoupled to structures in basement rocks, or whether some combination of the two may occur. The other two TRs address additional technical issues pertinent to a seismic hazard analysis of the Hanford Site, including the behavior of the YFB as a structural entity (Last et al. 2012) and existing estimates of fault recurrence and strain rates (Bjornstad et al. 2012).

\subsection{Programmatic Background}

In any PSHA, there are numerous sources of technical uncertainty. Among such sources are individual technical issues about which the appropriate resolution is uncertain and, often, about which there are opposing viewpoints and contention in the technical community. The Senior Seismic Hazard Analysis Committee (SSHAC) guidance for conducting PSHAs, to which the Hanford study will adhere, recommends that such uncertainties be characterized by the attachment of probabilities to the alternative resolutions of the issues (Budnitz et al. 1997).

These probabilities, which represent so-called epistemic uncertainties - that is, uncertainties reflecting limitations in technical knowledge — can be generated in one of several ways. The SSHAC guidance identifies four alternative bases for generating epistemic probabilities. These alternative methods are denoted as SSHAC Levels 1 through 4, representing increasing degrees of formality and effort. The SSHAC levels selected for the Hanford Site PSHA are

- SSHAC Level 3 for the seismic source characterization (SSC) elements of the analysis

- SSHAC Level 2 for the ground motion attenuation (GMA) modeling elements of the analysis.

The rationale for the selection of these SSHAC levels is documented elsewhere. ${ }^{1}$ For both Level 3 and Level 2 studies, the technical integrator (the TI, where the SSC and GMA elements of the Hanford PSHA each will have its own TI) has ultimate responsibility for development of the epistemic probabilities assigned within each of the technical issues. Per SSHAC guidance, these probabilities must reflect the range of opinions held in the expert technical community. The principal distinction between the Level 3 and Level 2 approaches is that, in the former, the TI assembles a panel of subject matter experts who physically meet to discuss the technical issues for which uncertainties or conflicting opinions exist. This dialog, along with any subsequent communications, provides the basis for the TI to attach the appropriate probabilities to the alternative issue resolutions. In contrast, a Level 2 analysis relies on less formal interactions of the TI with the subject matter experts, generally involving written and telephone communication, based on which the TI formulates the appropriate probabilities.

\footnotetext{
${ }^{1}$ Draft PSHA Work Plan, June 11, 2007, prepared by Kevin J. Coppersmith, Coppersmith Consulting, for Pacific Northwest National Laboratory under Contract 42259.
} 
The purpose of the TRs is to provide a convenient encapsulation of technical information about a single technical issue (or family of related issues) of relevance to the PSHA to serve as a resource to the TI and the subject matter experts in their deliberations. The criteria for selection of technical issues for the TRs are described in the next subsection.

The intent of a TR is not to advocate a specific resolution to a technical issue; that is, a TR is not intended to conclude that, despite contention in the technical community, one technical resolution should be preferred to another. Instead, the intent is to present the range of expert opinions and competing technical resolutions and to identify the data and analyses judged within the expert community to support each of these alternative resolutions. Thus, a TR does not advocate a specific viewpoint on the technical matter it expounds but instead is prepared as a convenience for the TI and team by assembling relevant data and analyses upon which they may deliberate.

\subsection{Selection of Topical Report Issues}

The conduct of a PSHA demands that varying degrees of uncertainty about numerous technical issues be addressed and reflected in the seismic hazard model. Uncertainty on the part of a PSHA TI with regard to the appropriate technical resolution of an issue can be the result of one of two situations:

Case 1. There is broad consensus among the technical community that uncertainty exists regarding the appropriate technical resolution of an issue.

Case 2. A range of competing opinions is held within the technical community regarding the appropriate resolution of a technical issue. In this case, any one member of the expert community may strongly favor a particular resolution, and the TI's uncertainty stems from the question of which competing opinion reflects the correct resolution of the issue.

Modeling the uncertainties associated with Case 1 is the more straightforward task because the TI can adopt the consensus view of the expert community. Case 2 is more problematic because the TI is left to evaluate the range of competing opinions and, based upon that evaluation (for SSHAC Level 2 and Level 3 studies), develop a probabilistic characterization of uncertainty for the subject issue. Given that this latter situation is the more challenging for the TI, the TR topics were selected to focus on issues that are defined by Case 2 .

Another discriminating factor in technical uncertainties is the degree to which uncertainty about a specific issue contributes to the resultant uncertainty in the seismic hazard. That is, some technical uncertainties are more important than others with respect to their impact on the results of the PSHA. Therefore, in selecting the issues addressed in the TRs, both the following criteria had to be met:

1. The issue is important to the seismic hazard. That is, the sensitivity of the calculated seismic hazard to the specific resolution of the issue is significant. Equivalently, uncertainty in the appropriate resolution of the issue results in a significant contribution to the total uncertainty in the estimate of the seismic hazard.

2. The correct resolution of the issue is a matter of contention in the expert community. That is, there are opposing schools of thought on the correct resolution, in contrast to a situation in which there is broad agreement that the correct resolution is uncertain. 
As a first step in identifying TR topics, Coppersmith Consulting developed a set of technical issues (Appendix A) expected to contribute to uncertainty in the seismic hazard at the Hanford Site. In that analysis, Coppersmith characterized qualitatively (in terms of high, medium, and low categories) each issue with regard to

- its anticipated importance to the hazard; that is, the degree to which it would be expected to contribute to the uncertainty in the seismic hazard - This evaluation was based not on the performance of detailed sensitivity analyses but rather on a limited base of existing sensitivity analyses for the technical issue as well as on the broad experience of the consultant in conducting PSHAs.

- the level of contention within the technical community regarding resolution to the issue.

Both SSC and GMA modeling issues were included in this evaluation. The SSC issue list drew primarily on the technical review by Zachariasen et al. (2006), on behalf of the U.S. Army Corps of Engineers, of the previous PSHA of the Hanford Site (Geomatrix 1996). The list of GMA issues was based on the experience of the consultant Coppersmith and his discussions with ground motion specialists.

Based on this list of issues and the associated assessments of importance and levels of contention (Appendix A), PNNL personnel, supported by Coppersmith and Steve Reidel (a geology consultant with Washington State University), applied the selection criteria described previously to determine which technical issues would be addressed in the TRs. Three issues were identified as meeting the selection criteria, all of which are related to SSC. Although certain GMA issues, such as those associated with the next generation attenuation (NGA) models, were identified as having the potential to have significant impact on uncertainty in the seismic hazard, these issues were not assessed to be sources of significant contention within the expert community. The three SSC issues selected as TR topics were

- whether the Yakima Fold Belt is best represented by a coupled or uncoupled tectonic model, or some combination of both - The 1996 PSHA of the Hanford site attached greater weight to the model in which the faults coring the Yakima folds are unconnected to the faults in the basement. This weighting was questioned in the review of the PSHA model by Zachariasen et al. (2006). This TR addresses this issue.

- whether observation of activity along one Yakima fold structure should be considered an indicator of behavior along all Yakima fold structures - The 1996 PSHA of the Hanford Site (Geomatrix 1996) was based on the assumption that if one fold structure were active, then this did not necessarily imply that all Yakima fold structures were active. This assumption was questioned in the review of the PSHA model by Zachariasen et al. (2006). This issue is addressed in a companion TR (Last et al. 2012).

- whether the uncertainty ranges in slip rates should be wider than those used in the previous Hanford PSHA, which were based on post-Columbia River Basalt Group ages - This issue was raised in the review of the 1996 PSHA model by Zachariasen et al. (2006). This issue is also addressed in a companion TR (Bjornstad et al. 2012).

This TR addresses the first of these technical issues, which was assessed to have a high level of contention with up to moderate potential for impact on the hazard estimate (see Appendix A). 


\subsection{Report Objectives and Structure}

The objective of this report is to summarize the range of opinions and supporting information expressed by the expert community regarding whether a coupled or uncoupled model, or a combination of both, best represents structures in the Yakima Fold Belt. This report defines the relevant alternative conceptual models and the arguments and data that support those models.

A brief synopsis of the generally accepted geologic history of the YFB is given in Section 2, followed by a discussion in Section 3 of arguments found in the literature supporting either the coupled or uncoupled models. Another alternative model discussed in Section 3 is one in which some structures are coupled while others are uncoupled. It is not the intent of this report to resolve this technical issue, nor is the list of references exhaustive. Rather, the objective is to present the issues and supporting data for each of the models in a way that will help the PSHA technical integrator and expert panel determine the appropriate probabilities to attach to each competing model. Appendix A includes a description of the process and information used to identify the three TRs for preparation by PNNL. Appendix B is an annotated bibliography of literature sources relevant to this issue. 


\subsection{Technical Background}

The importance of "the use of coupled versus uncoupled fault models" to describe the development of geologic structures found in the Columbia Plateau is related to estimates of the size of earthquakes along faults. Earthquake size is based on the downdip and lateral extent of the fault plane, which in part determines the maximum magnitude of the earthquakes along the plane. Faults that are uncoupled from basement faults (Figure 2.1) are obviously smaller in downdip extent and would consequently be assumed to be capable of a smaller maximum magnitude. However, the frequency of such earthquakes may be greater than earthquakes along faults that are coupled to the basement. Coupled faults have a greater downdip extent and are assumed to be capable of a larger maximum magnitude. In the Columbia Plateau, there is little or no directly observable, conclusive evidence for either model, allowing a range of interpretations of the less direct evidence. Some aspects of the geology of the Plateau generally agreed upon by the expert community are discussed below.

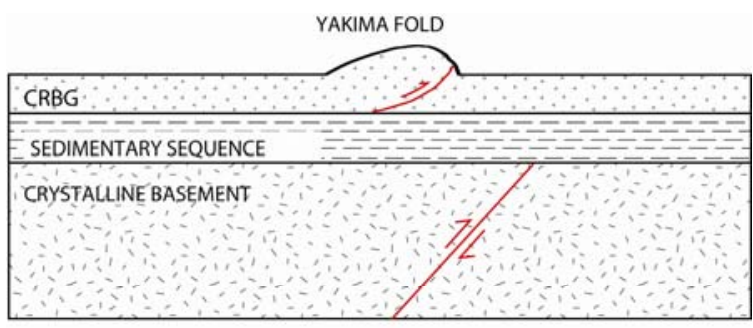

UNCOUPLED MODEL

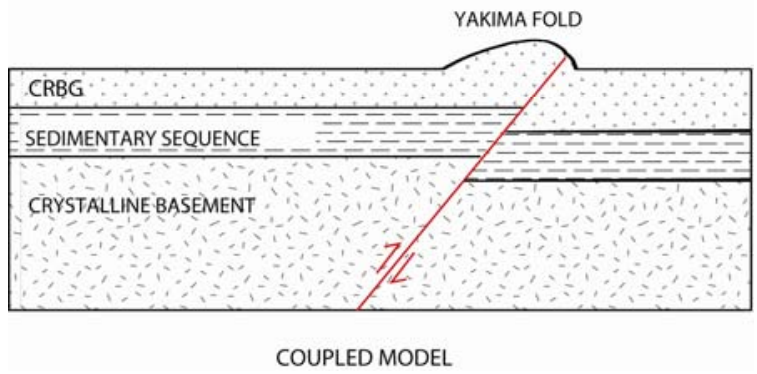

Figure 2.1. Coupled Versus Uncoupled Tectonic Models (after Geomatrix 1996, Figure 2)

The crustal structure in the Columbia Plateau consists of three major layers: $0-5 \mathrm{~km}$ of basalts of Miocene Columbia River Basalt Group (CRBG) overlying 0-6 km of relatively incompetent Eocene fluvial deposits and Oligocene volcaniclastic and siliciclastic sediments, all of which are underlain by either crystalline basement (generally in the eastern part of the Columbia Basin) or Paleogene or older continental-margin rocks and accreted terranes, primarily in the western part (Campbell 1989; Montgomery 2008). The Yakima Fold Belt structural subprovince occurs in the western portion of the Columbia Basin and is composed of asymmetrical folds and related faulting formed under north-south compression that continues to this day. Folds generally range in trend from northwest-southeast to eastwest in the northern and central portions of the Plateau to northeast-southwest in the southwestern portion (Figure 2.2). 


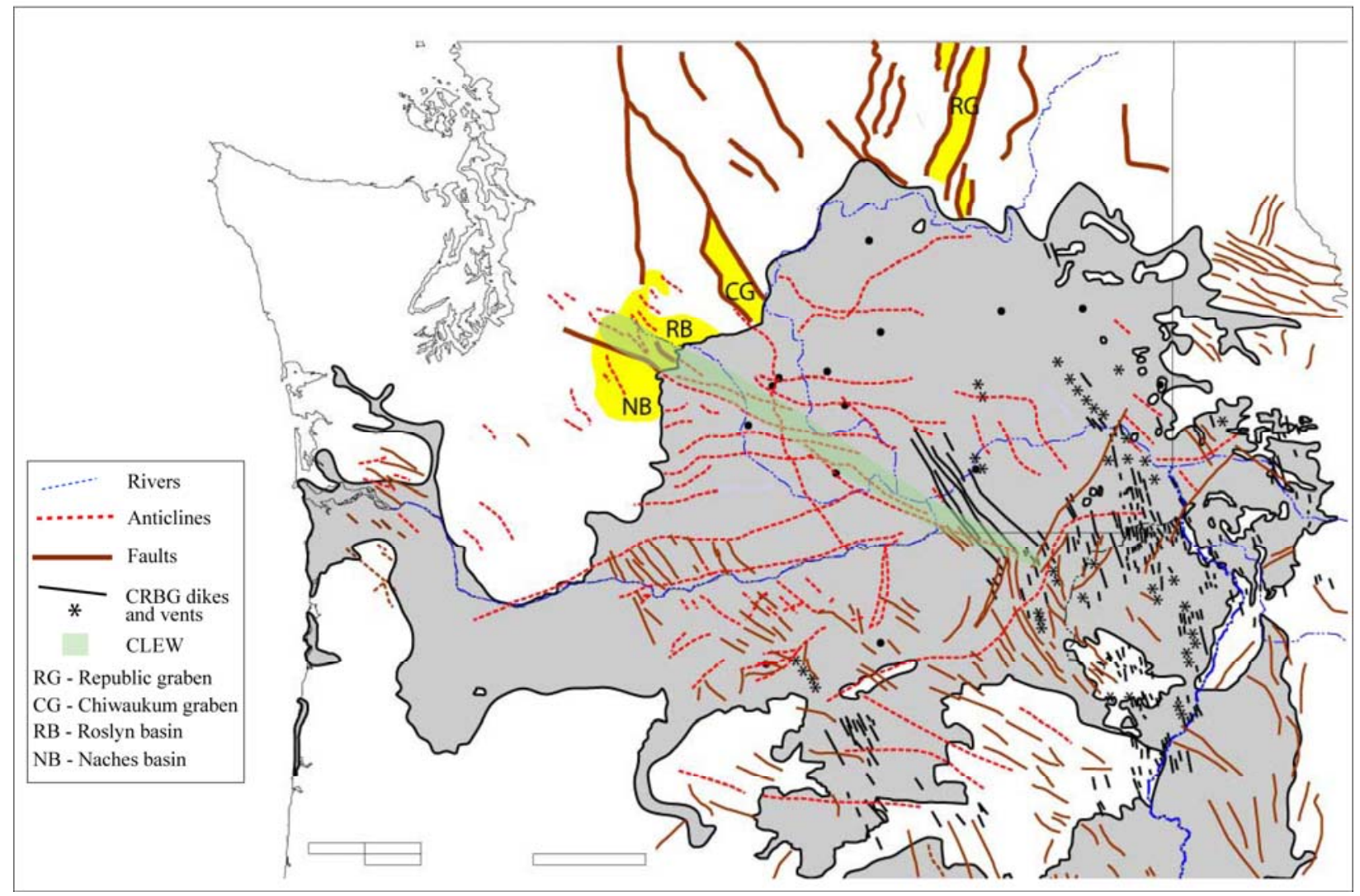

Figure 2.2. Major Structural Features in the Columbia Basin (from Reidel and Tolan 2007)

Field mapping has shown that early Miocene and older continental siliciclastic and volcaniclastic rocks occur in grabens separated from horsts by high-angle faults along the western margin of the CRBG (Tabor et al. 1984; Campbell 1989; Montgomery 2008). These sediments thin and pinch out to the east and southeast, resulting in basalt overlying accreted terrane or crystalline basement rocks (Reidel et al. 2006). Oil and gas exploration wells and various geophysical data have shown that graben-like subbasins are filled with the same formations and extend beneath the CRBG in the western half of the Columbia Basin (Campbell 1989; Saltus 1993; Jarchow et al. 1994; Montgomery 2008). Overall, subsidence of the Columbia Basin has been occurring since at least Eocene time and continued into the Pliocene, first with sedimentation and then with basalt accumulation keeping pace with the subsidence (Reidel et al. 1989, p. 248). Reidel et al. (1994) state that subsidence is the dominant tectonic feature in the basin, although the folds are the most visible.

Structural deformation of the basalts is more gentle near the margin of the CRBG and increases toward the interior of the YFB (Campbell 1988; Reidel and Campbell 1989, p. 283). Reidel et al. (1989, 1994) noted that folds are typically found over areas where subsidence allowed a thick accumulation of sediments between the basement rocks and basalt and that fold growth may be correlated with basin subsidence, a conclusion also reached by Mège and Ernst (2001).

Several theories have been proposed to explain the development of the structural features now seen in the Columbia Basin. Most theories hypothesize that oblique subduction of the Juan de Fuca plate has caused the north-south compressive stresses since at least the Miocene in the Columbia Basin. Davis 
(1981, p. 2R C-3) interprets eruption of the CRBG as a "back-arc phenomenon related to the accelerated subduction of oceanic lithosphere.” Reidel et al. (2006) suggest that northwest-trending CRBG dikes follow pre-existing weaknesses in the accreted terrane and basement rocks, while Hooper and Conrey (1989, p. 293) suggest the dikes were controlled by back-arc spreading associated with Basin and Range extensional forces. Davis (1981, p. 2R C-3) suggested back-arc spreading related to subduction caused the CRBG eruptions with dike swarms controlled by the pre-existing weakness between the Precambrian craton and accreted terranes. An alternative theory, that the Yellowstone mantle plume located in southern Oregon ultimately caused resumption of Columbia Basin subsidence $17 \mathrm{Ma}$ and north-south compressive stresses resulting in the YFB, has been proposed by Mège and Ernst (2001).

McCaffrey et al. (2007) used Global Positioning System (GPS) measurements to develop a model showing dextral block rotation in the mid-Columbia resulting in northeast-southwest to east-west compressive strain. They conclude that rotation of the blocks is caused by oblique subduction of the Juan de Fuca plate and that the northeast orientation and decreasing strain rates inland from the coast are typical of elastic strain rates resulting from locking on a subduction zone. However, Mege and Ernst (2001, p. 114) cite little or no rotation of dikes based on others' reports (Martin 1984; Hagstrum et al. 1999; Ernst and Buchan 2001), and Reidel et al. (1984) demonstrated that anticlines but not synclines in the YFB show small-scale rotation, which would support only localized rather than regional rotation.

Cenozoic volcanism beginning in the Eocene is thought to be either 1) related to (Davis 1981), or 2) the cause of (Montgomery 2008), block faulting that resulted in sub-basins such as the Chiwaukum graben. This faulting was oriented northwest-southeast (Campbell 1989; Tabor et al. 1984) with a weaker conjugate northeast-southwest fault set along the western CRBG margin (Montgomery 2008; Tabor et al. 1984). Montgomery (2008) implies that stresses prior to eruption of the CRBG may have been different from those reflected by YFB development when he states there was a shift to north-south compression, coeval with extrusion of the CRBG that generated the thrust-bound structures of the YFB. 



\subsection{Technical Positions}

A number of tectonic models have been proposed to explain the origin and evolution of the Yakima Fold Belt, but there is no consensus in the expert community. Two main models are discussed in detail in Geomatrix (1996) and Zachariasen et al. (2006). The first is the coupled (thick-skinned) model, in which faults associated with folds extend through the entire seismogenic crust from the basement up to or near the surface and movement along the fault is usually the cause for the fold (Yeats 1986; Berberian 1995; Crider et al. 2003). In the uncoupled (thin-skinned) model, faults associated with folds are not connected to faults in the basement rocks. Uncoupled faults may have formed in response to folding-for example, the thrust fault at the base of the steep north slope is the result of kink folding at depth (Cowan 1981; Price and Watkinson 1989) — or they may result from movement along a décollement at the base of the basalts, in the sub-basalt sediments or at the contact between the sediments and basement rocks (Laubscher 1981; Bruhn 1981; Mege and Ernst 2001). Such uncoupled faults may merge at depth into a regional décollement in either the basalts or underlying sediments, or uncoupled faults may disperse into aseismic, distributed shear within the sub-basalt sediments that occur throughout much of the central Columbia Basin. Geomatrix (1996, p. 3-8) suggests that fold and thrust mechanisms are restricted to primarily the CRBG and do not extend into the sub-basalt sediments or basement.

High-angle reverse faults are assumed to imply faulting is related or coupled to basement rocks, while low-angle reverse or thrust faults imply that folding and faulting are related to a décollement or a zone of distributed shear in the weaker sub-basalt sediments.

There has been little direct evidence of the layers and structures beneath the basalts upon which to base interpretations. Ongoing oil and gas exploration will provide some of the data needed to understand subsurface structures. High-quality geophysical methods, interpretive techniques, and wildcat drilling are starting to shed light on the deep subsurface of the Columbia Plateau (Saltus 1993; Jarchow et al. 1994; Montgomery 2008). Unfortunately, much of the data is proprietary for long periods of time, and it may be several years before more details of their findings become publicly available.

In the following discussion of the three alternative conceptual models (ACMs), some phrases are used in specific ways. The term Yakima folds is used here for only those folds developed in the Columbia Plateau under north-south compression. Older folds such as the Hog Ranch-Naneum anticline began to form prior to eruption of the CRBG and are not considered to be YFB structures in this topical report. Reverse and thrust faults related to each of the Yakima folds are referred to below as fold-related or foldassociated faults, distinguishing them from other, older faults such as the Leavenworth and White RiverNaches River faults that cut the basalts along the western margin of the CRBG.

\subsection{Alternative Conceptual Model 1}

\section{The Yakima Fold Belt structures are coupled to the basement rocks.}

Types of evidence that support the model that faults in the CRBG are coupled to structures in the underlying accreted terrane or cratonic basement rocks include continuation of structures from the basalt into older rocks, geophysics that can delineate features throughout the seismogenic crust, and earthquake 
hypocenters that align along fault planes that can be traced from the basalts to the basement rocks. The mechanics of folds and faults similar in appearance to the YFB also have been used to support arguments for coupling. The following sections discuss literature that provides data supporting coupling.

\subsubsection{Mechanical Arguments}

Based on thinning and thickening of basalt flows throughout the Saddle Mountains, Reidel (1984, p. 973) concluded that "folding began prior to or simultaneously with the oldest basalt flows" although he also notes that it is unknown whether the basement is involved or not. In folds that have been more deeply eroded, such as the water gap through the Frenchman Hills or the Columbia Hills at Rock Creek, faults are high-angle reverse faults (Reidel et al. 1994, p. 166), which may imply coupling to underlying structures. However, these same dip angles could be interpreted also as steepening of fault ramps as they approach the surface.

Yeats (2007) compares the YFB to areas around the world where reverse faults nucleating near the brittle-plastic transition are expressed at the surface by broad warps and bending-moment faulting with little to no expression of primary fault-plane surface ruptures. He specifically suggests that ruptures seen near the base of the steeply dipping north limbs of Toppenish and Ahtanum Ridges represent bending moment faults above a blind fault (Yeats 1986, p. 69) rather than surface rupture along the main fault plane as suggested by Repasky and Campbell (1998).

The Zagros fold-thrust belt in Iran has physical features similar to those of the Yakima Fold Belt, with a series of anticlinal ridges formed under compression and faulting identified at the bases of at least some of the anticlines. Weak Hormuz salt beds act as a plastic layer that decouples deformation along high-angle reverse faults in the underlying strong basement rocks ( $\mathrm{Ni}$ and Barazangi 1986, p. 8210). Lacombe et al. (2006) interpret the Zagros folds to have formed as symmetrical buckle folds with no associated thrust faults in more rigid rocks overlying a master décollement above the Hormuz salt beds. The entire area was further deformed when older, normal faults in the basement were reactivated as blind, high-angle reverse faults that formed topographic steps where anticlinal cores are uplifted. The Zagros fold-thrust belt is given as an example of blind reverse faulting extending from the basement through weaker sedimentary rocks that causes uplift at the surface that could be argued as a model for the Yakima Fold Belt (Zachariasen et al. 2006, p. 2-9).

\subsubsection{Continuity of Structures Arguments}

Several of the arguments supporting coupling revolve around pre-basalt age faults or structural trends that appear to influence the YFB and continue beyond the margin of the CRBG but are not themselves part of the YFB as defined above. Included in these are folds and faults of the Olympic-Wallowa lineament, the Leavenworth fault zone, White River-Naches River fault zone, and Hog Ranch-Naneum anticline.

The portion of the Olympic-Wallowa lineament that crosses the Columbia Basin, the Cle ElumWallula deformed zone (CLEW), is an alignment of topographic features. These features include deformation along Manastash Ridge on the CRBG margin and the southern end of the Straight Creek fault, which some geologists have mapped as splaying and bending to the southeast; the direction changes in Umtanum, Yakima, and Rattlesnake anticlines; the Wallula Gap fault; and a series of doubly plunging 
anticlines between Rattlesnake Mountain and Wallula Gap. Reidel et al. (1994) found no individual structure identified with this alignment of features, however.

The Leavenworth Fault system near Wenatchee forms the western boundary of the Chiwaukum graben and aligns with, and was probably a factor in controlling development of, the Hog Ranch-Naneum Ridge anticlinal structure (Campbell 1988, p. 22). However, the faults and folds along the eastern boundary of the graben do not extend into, and appear unrelated to, those in the CRBG. The Hog RanchNaneum Ridge structure controlled distribution of the sub-basalt sediments as well as CRBG flows (Chamness and Tolan 1983; Campbell 1989, p. 220; Reidel et al. 1989) and increased structural relief of the Frenchman Hills, Saddle Mountains, Umtanum Ridge, and Yakima Ridge anticlines crossing it (Reidel and Campbell 1989, p. 285). Faulting associated with the structural high forming the western boundary of the Chiwaukum graben carries upward into the basalt but vertical offset is small compared to pre-basalt faulting. Post-basalt faults are less numerous and to date cannot be traced southward of Whiskey Dick Mountain where the Hog Ranch anticline crosses the Frenchman Hills (Campbell 1988, p. 41; Campbell 1989).

The White River-Naches River fault zone has been identified as a major boundary between two tectonic blocks with differing origin, composition, and structural orientation, aligned with and possibly demarking the south margin of the CLEW (Campbell 1988, pp. 35-38; Reidel and Campbell 1989; Reidel et al. 1994, p. 164). Campbell (1988) mapped faults within this zone that affect both basalt and older volcaniclastic rocks. This fault system demarks a significant change in orientation of several YFB structures. In the tectonic block northeast of the White River-Naches River fault system, faults and folds in pre-Tertiary through Pliocene rocks trend northwest-southeast $\left(\sim \mathrm{N} 60^{\circ} \mathrm{W}\right)$. In the block to the southwest of the fault system, faults and folds in the pre-Tertiary and early Tertiary rocks trend east-west to southwest-northeast $\left(\mathrm{N} 5^{\circ} \mathrm{E}\right.$ to $\left.\mathrm{N} 20^{\circ} \mathrm{W}\right)$, while middle to late Tertiary rocks generally have east-west trends similar to the YFB (Campbell 1989). He suggests the White River-Naches River fault zone controlled sub-basalt sediment deposition and influenced YFB fold development as far east as Yakima, separating east-northeast-trending folds in the south from northwest-trending folds to the north (Campbell 1989, p. 217). The White River-Naches River fault zone is thought to form the southern boundary of the CLEW (Campbell 1988, p. 35-38; Reidel et al. 1994, p. 164).

The Straight Creek fault zone appears to bend southeast where the zone intersects the CLEW (Tabor et al. 1984; Campbell 1989), although Cheney (2003) shows the Straight Creek fault as continuing to the south, not bending southeast. Faults within the southeasterly trending portion of the fault zone control sub-basalt basins and horsts such as Manastash Ridge and, in at least one case (Taneum fault), cut both basalt and older rocks (Campbell 1988, p. 34). Campbell notes that all other pre-basalt faults in this area die out either laterally or vertically.

The Wallula fault zone forms the southern boundary of the CLEW at the border between Washington and Oregon (Reidel et al. 1994, p. 161). Quaternary faulting has been documented in trenches along the fault trace (Woodward-Clyde, unpublished data ${ }^{1}$ ), with last movement thought to be right lateral. Reidel and Tolan (1994) suggest that dikes of Ice Harbor Basalt occur on both sides of the Wallula fault zone

1 Task D-4, Wallula Fault Trenching and Mapping; 1981 draft report prepared for the Washington Public Power Supply System by Woodward-Clyde Consultants, San Francisco, California. 
southeast of Wallula Gap. Mann and Meyer (1993, p. 868) note a change in OWL structural style as it crosses what they interpret as the boundary between accretionary terranes to the continental craton and suggest basement structures influenced those in the Columbia River basalt. The "Rattles" extend northwest from Wallula Gap and may represent en echelon folding above a blind fault, in this case the Wallula Gap fault. Schultz (2000, p. 12043) describes a mechanical process that causes en echelon arrays of backthrust faults nucleated at depth near a primary blind fault, with the blind fault potentially propagating to the surface along a steeply dipping anticlinal limb. Activity along Wallula Gap fault is not directly part of the Yakima folds, but because the Rattles and other structures line up with it, it either is related or has controlled development of the folds.

Reidel (1984, p. 968) suggests the northwest-trending Smyrna anticline and the boundaries between the Smyrna Bench-Sentinel Gap segments, Saddle Gap-Eagle Lakes segments, and McDonald SpringsSentinel Gap segments of the Saddle Mountains are controlled by northwest-trending basement structures, and clusters of microseismicity near Corfu and Chelan may be related to an extension of the Chiwaukum graben (Johnson 1989). The boundary between the Saddle Gap-Eagle Lakes segments lies along the west side of an aeromagnetic anomaly resulting from the ponding of basalt flows along the eastern flank of the Smyrna anticline (Reidel 1984, p. 969) both of which coincide with the suture zone between continental crust and accreted terranes (Reidel et al. 1994, p. 167). More recently, structures trending N30-40 ${ }^{\circ} \mathrm{W}$ cutting across the Yakima folds and the Palouse Slope have been identified as likely being related to basement structures (Reidel et al. 2006). The northeast-trending Hite fault may be coupled to the basement as it marks a change in CRBG dike orientation from N-N20W east of the fault to N40-50W west of the fault (Reidel et al. 2006).

Several YFB folds extend into the Cascade Range, and at least two, the Columbia Hills and Horse Heaven Hills, continue across the Columbia River into Oregon (Beeson et al. 1989, pp. 231, 238; Tolan and Reidel 1989), suggesting these anticlines and their associated faults are coupled to basement rocks. High-angle northwest-trending strike-slip faults cut across multiple folds in the southwestern portion of the CRBG, forming fold segment boundaries in many cases, and may also be related to basement structures. However, the basalts lie above a thick sequence of older volcanic and volcaniclastic sediments (Bentley et al. 1980, Campbell 1989) with unknown structural features. It is not clear how the sub-basalt sediments or structures in those sediments or the unexposed basement rocks may have influenced development of faults and folds in the basalt along the eastern part of the Columbia River Gorge.

\subsubsection{Geophysical Arguments}

Magnetotelluric surveys by the U.S. Department of Energy in the 1980s suggest that the CRBG is thinner beneath Rattlesnake Mountain than in the adjacent syncline. This is corroborated by thinning and pinching out of flows across this and other anticlines (Reidel et al. 1989). The magnetotelluric surveys also suggest that a basement high may occur below Rattlesnake Mountain beneath several kilometers of sedimentary rocks (Campbell 1989, p. 217). This may imply coupling between Rattlesnake Mountain and the underlying basement.

Gravity data indicate a crustal feature aligned with the CLEW that follows a basement ridge west of Hog Ranch-Naneum Ridge and a gravity gradient east of Hog Ranch-Naneum Ridge (Saltus 1993, p. 1258). The feature does not offset the Hog Ranch-Naneum Ridge, suggesting any strike-slip movement predates that Eocene- to Oligocene-aged structure. 


\subsubsection{Seismicity Arguments}

Zachariasen et al. (2006, p. 2-5) point out that while the sub-basalt sediments have lower seismicity than the basalt or basement layers, they are nonetheless seismogenic, and although weaker than the rocks above or below, these sediments are capable of co-seismic rupture. A review of the annual Hanford seismic reports (e.g., Rohay et al. 2007) between 1998 and 2007 shows that $23 \%$ of the earthquakes detected in the Columbia Basin by the Hanford seismic network occur between 5 and $10 \mathrm{~km}$ depth, coincident with the sub-basalt sediments in most areas.

To date, there has been no seismic delineation of deep-seated fault planes that extend up to or near the surface. This neither proves nor disproves the existence of deep-seated fault planes, however, given the low seismicity of the region and the relatively short time seismic monitoring has been in place.

\subsection{Alternative Conceptual Model 2}

The Yakima Fold Belt structures are uncoupled from the basement rocks.

The types of evidence that could indicate that faults in the CRBG are not coupled to the underlying accreted terrane or cratonic basement rocks are essentially the antithesis of those that would prove coupling. These data types include no evidence of continuation of structures from the basalt into older rocks, geophysics that can delineate features in the basement and show no correlation between surface and deep structures, and earthquake locations that do not align along a fault that can be traced from the basalts to the basement rocks. The mechanics of folds and faults similar in appearance to the YFB have been used to also support arguments for structures uncoupled from the basement. The following discusses literature that provides data supporting the position that structures are uncoupled from basement rocks.

\subsubsection{Mechanical Arguments}

Yakima Fold Belt development and determination of fold wavelengths began by the time early Grande Ronde flows were erupted (Reidel 1984, p. 969; Watters 1989, p. 288). Structural and mechanical analysis of the geometry of the Yakima folds was consistent with critical wavelength buckling of multiple elastic layers (basalts) over relatively thick and mechanically weak sub-basalt sediments (Watters 1989). Based on borehole data and mapping of Umtanum Ridge, the Umtanum anticline is a kink fold with a $30-40^{\circ}$ south-dipping thrust fault that developed to accommodate strain within the fold (Price 1982; PSPL 1981, p. 2N-14; Price and Watkinson 1989, p. 278). Cowan (1981, pp. 2S-2, 2S-6, 2S7) concludes that the thrust faults are not related to more deeply rooted faults because of the segmentation and en echelon nature of the folds and their opposing vergences, and that the low fault dip angle of $30-40^{\circ}$ on the Umtanum fault was not compatible with a deep-rooted fault.

Recent oil and gas exploration drilling on the south limb of the Saddle Mountains anticline indicates the Saddle Mountains fault dips at a low angle to the south (Montgomery 2008). Low-velocity zones in seismic reflection data along the Hog Ranch-Naneum Ridge structure were interpreted by Jarchow et al. (1994, p. 268) to dip $30^{\circ}$ south and by Lutter et al. (1994, p. 1278) to dip $15-45^{\circ}$ south, and are thought to be breccia along the thrusts dipping from the north vergent limb of Whiskey Dick and the Boylston 
anticlines to the base of the basalt. Some of the faults showing large displacements in the middle of the Columbia Basin die out as they approach the northwestern CRBG margin (Campbell 1989, p. 220).

Segmentation and vergence changes of the Yakima Fold anticlines are thought to be indicative of uncoupled décollement rather than coupling to basement structures. Tear or cross faults between segments and/or vergence changes in the central basin are confined to the anticlinal ridges and are not deep-seated structures (Reidel et al. 1989, p. 251).

Based on geometrical considerations only, Bruhn (1981) preferred structural ramps above a décollement to explain the long, gently dipping limbs of asymmetrical folds. He speculated that ramped faults with a dip of $30-45^{\circ}$ could develop from a regional décollement or a group of localized detachments at a depth of 3 to $5 \mathrm{~km}$. In his model, kink folds would be second-order structures caused by perturbations in stress near the ends of the ramps.

In the Zagros fold-thrust belt in Iran, which has physical features similar to the Yakima Fold Belt, Ni and Barazangi (1986, p. 8210) interpret weak Hormuz salt beds acting as a plastic layer that decouples deformation along high-angle reverse faults in the underlying strong basement rocks from folds in the surface sediments, essentially forming a blind reverse fault..

\subsubsection{Continuity of Structures Arguments}

Most faults found in pre-basalt rocks along the northwestern margin of the basalt do not continue into the CRBG, and many have trends that do not coincide with faults and folds found in the CRBG (Campbell 1988). Many of the Yakima folds decrease in amplitude or die out toward the margin.

Campbell and Bentley (1981, p. 522) interpreted the Mill Creek fault on Toppenish Ridge as a décollement thrust bounded by tear faults capable of generating a large earthquake that caused Quaternary surface ruptures. Campbell et al. (1995) investigated some of the surface rupture features and concluded the main fault had been active up to five times in the past 165,000 years; at least one large earthquake with $3.5 \mathrm{~m}$ of offset occurred during that period. Yeats (1986) interprets the fan surface ruptures as caused by bending moment of the concave face of the syncline above a blind thrust.

Lateral continuity of faults associated with folds diminishes along strike with increasing distance from areas with the greatest structural relief. Reidel et al. (1989, p. 251) give the example in which the Rattlesnake Mountain anticline plunges toward the Yakima River water gap. Mapping along the water gap found no evidence of faulting, although the RAW trends through the area. Campbell (1988, p. 34) also notes that most major folds and faults in the interior of the YFB diminish or die out before reaching the CRBG margin.

\subsubsection{Geophysical Arguments}

Montgomery (2008) provides a preliminary interpretation of gas exploration data (integrating gravity, magnetic, and seismic data with geologic and geochemical data from wells and outcrops) indicating that "thrusted folds in the basalt have a complex, variable relationship to structures at depth" and that while some faults may be rooted in older basement faults, “... it is now speculated that much of the basalt cover responded as a separate structural entity relative to the underlying sedimentary section” (Montgomery 
2008, p. 5). Illustrations in his article show some faults originating in the sub-basalt sediments, but basement faults do not coincide with surface folds or faults.

A high-resolution seismic line was run along the Hog Ranch-Naneum anticline from near Wenatchee to just south of Yakima Ridge (Lutter et al. 1994; Jarchow et al. 1994). Neither report noted any geophysical evidence for structures related to the CLEW in the vicinity of Umtanum and Yakima Ridges, although their seismic line extended across that zone. Based on these data, Jarchow determined that the reverse faults along the north-vergent side of the Boylston and Frenchman Hills anticlines are linear, dip $30^{\circ}$ to the south, and extend to the base of basalt where they merge into a décollement surface (Lutter et al. 1994, p. 1285, Figure 7). They do not interpret any faulting through the sub-basalt sediments. Jarchow et al. (1994, p. 268) conclude that "base-of-basalt depth variations do not correlate with surface structure" and that the Boylston anticline is actually over a low in the basalt-sediment interface. These points would suggest that the basalt structures are not directly controlled by basement structures.

\subsubsection{Seismicity Arguments}

Levels of seismicity in the basalt and basement are higher than in the sub-basalt sediments. Review of annual Hanford seismic reports (e.g., Rohay et al. 2007) between 1998 and 2007 indicates $42 \%$ of detected earthquakes in the Columbia Basin occurred in basalt ( $0-5 \mathrm{~km})$ and $35 \%$ occurred in basement rocks (10-25 km), while 23\% occurred in the sub-basalt sediments. Rohay and Davis (1983, p. 6-7) found that except for an apparent alignment of shallow seismicity along the Saddle Mountains, earthquakes in the Yakima Fold Belt do not align with mapped faults and are essentially random events. Geomatrix (1996) interprets lack of alignment between deep and shallow earthquakes to mean faults related to folding are not coupled to basement. However, Finnegan and Montgomery (2003) describe relatively high-angle planar, east-west-oriented clusters of earthquake hypocenters beneath Yakima and Umtanum Ridges along the Yakima River; they associate narrowed canyons and steeper gradients where the river cuts through these two ridges with possible continuing deformation.

Based in part on his interpretation of seismicity in the Columbia Basin, Miner (2002, pp. 56, 86) concludes the Yakima Fold Belt is controlled by a décollement at a depth of 5 to $12 \mathrm{~km}$ but that there are also clear hypocenter alignments that extend through the entire seismogenic crust to a depth of 20 to 25 $\mathrm{km}$. He suggests that seismicity appears to define steeply dipping planes along the axial surfaces of the folds at depth in his eastern transect of the basin (Miner 2002, p. 55, Figure 17). His interpretation of the seismicity further to the west (Miner 2002, p. 60, Figure 18) is less clear on the presence of a décollement between a depth of 5 and $10 \mathrm{~km}$.

\subsubsection{Alternative Conceptual Model 3}

The Yakima Fold Belt comprises a combination of both coupled and uncoupled components.

As can be seen in the preceding discussions, there is good support for aspects of both coupled and uncoupled models in the Yakima Fold Belt. Several authors have implied that there are both coupled and uncoupled structures in the Columbia Plateau, although they have not presented a model that combines these structures into a unified, coherent representation (Campbell 1989; Montgomery 2008). Many of the 
coupled features exist in older rocks and continue into the basalt, and most trend northwest-southeast. Features that argue for coupling include

- the block-faulted Chiwaukum graben (including the north-south-trending Hog Ranch-Naneum Ridge), Naches basin, and Roslyn basin

- associated uplifted blocks such as the Manastash Ridge and Stuart blocks

- the White River-Naches River and possibly the Straight Creek fault zones

- low-amplitude folds on the Palouse Slope

- the high angle of a few thrust faults associated with folds

- the changes in orientation and intensity of deformation of folding and faulting associated with the CLEW.

Many of these features extend laterally only a few tens of kilometers into the basalts, however, before evidence of them dies out. Other features, such as the continuation of the Columbia Hills and Horse Heaven Hills anticlines into the Cascade Range, the Wallula fault zone, and the change in orientation of basalt dikes across the Hite fault, cannot be traced into older rocks directly but are thought to be related to basement structures.

None of the features above explain the pattern of folding and faulting seen throughout the YFB, however. Many of the arguments for uncoupling and/or against coupling are related more directly to the basalt folds, including

- decreasing levels of YFB deformation toward the CRBG margin

- segmentation of folds and associated reverse faults

- changes in vergence within and between folds

- tear faults limited to and contemporaneous with folds that often occur at segment boundaries

- differences in seismicity between the basalts, sub-basalt sediments, and the basement

- low angles measured for some thrust faults.

In addition, geophysics data indicate

- Few if any features extend from the basalt down into the basement.

- Highs in the base of basalt do not necessarily correspond to highs in the basement.

- There are few if any basement features related to the CLEW.

- Possible ramp structures within the sediments extend up into the basalts and surface along the steeply dipping limb of the anticlines.

Tectonic models for the Columbia Basin need to be able to account for all of the evidence above, especially those data that seem to be in conflict. Campbell (1989) suggests two models that could explain the dissimilarities in the basalt and sub-basalt deformation seen along the northwestern margin of the 
CRBG-1) distributed shear along small faults and folds in the basalt that could have accommodated the larger-scale faulting seen in subparallel faults in the adjacent older rocks or 2) a décollement causes basalt folds to not align with sub-basalt folds. Mann and Meyer (1993, p. 869) propose a change from coupled to uncoupled deformation to account for the transition of the Rattles from en echelon in the south near Wallula Gap to in-line axial trends farther northwest. They further suggest that the predominance of Columbia Plateau seismicity in the 2- to 5-km depth range may be related to such a detachment.

Lacombe et al. (2006) interpret the Zagros folds in Iran formed as symmetrical buckle folds without associated thrusting above a master décollement in response to compressive forces. These folds were deformed further when older, normal basement faults were reactivated as blind, high-angle reverse faults that cut across the décollement to form topographic steps where anticlinal cores are uplifted. Miner (2002, p. 59) suggests almost the opposite sequence of events in the Columbia Basin, with deep-seated structures originally controlling the surface faults that were later truncated by a décollement that stepped upward as the Tertiary section thickened.

A hybrid model for the Yakima Fold Belt and Columbia Basin might include the following features:

- North-south compression is the dominant force and acts on all three crustal units, although deformation rates may have diminished since the Miocene. Subsidence is the dominant tectonic feature.

- Seismicity occurs in all three crustal units, although the sedimentary sequence historically experiences notably fewer earthquakes and may deform more through distributed aseismic shear or plastic deformation.

- Based on oil and gas data and geophysics, basement structures do not generally align with the Yakima folds, and detachment faults between the basement and sedimentary sequence and within the sediments probably extend into the basalt and may be the cause of the fold.

- Sub-basalt rocks have developed sub-basins or grabens bounded by faults, both of which extend beyond the western and northwestern margin of the CRBG; in some areas, the faults have affected the basalts or have controlled fold growth (Wallula, Hite, White River-Naches River, Taneum, and Leavenworth faults).

- Deformation in the YFB is greatest in the interior and decreases toward the margins of the CRBG.

Movement on a basement fault would affect the overlying sediments, which may in turn absorb much of the resulting deformation or translate it into movement along the detachment faults. Movement along the detachment faults could occur at the same time or be delayed by significant periods of time. The western margin of the CRBG may be under somewhat different stresses; it has been uplifted by the Cascades and may be affected more by the rotation and shear caused by the oblique subduction of the Juan de Fuca plate, causing dextral strike-slip faults such as the Luna Butte fault. 



\subsection{Recommendations}

No simple methods are available to reduce uncertainty on the question of which faults and folds in the Yakima Fold Belt are coupled or uncoupled to basement structures, or whether one model applies to all the structures. Data currently being collected for oil and gas exploration in the Columbia Basin provide the best opportunity to understand the relationships between structures in the basalt and the rocks underlying it.

Detailed geophysics data have been collected and can be purchased from the oil or gas companies. However, they are expensive and ultimately proprietary. It may be difficult or even impossible to use such data to publicly support probabilistic seismic hazard analysis assumptions. Similar geophysical studies could be funded by any interested party but would probably require significant resources.

Deep boreholes meant to penetrate into sub-basalt sediments continue to be drilled in several areas around the Columbia Basin. Data from these wells are given to the Washington State Department of Natural Resources and become available after one year. However, these data would need to be interpreted by individuals who are both experienced in reading the logs and knowledgeable of the potential geologic correlations. 



\subsection{References Cited}

Beeson MH, TL Tolan, and JL Anderson. 1989. The Columbia River Basalt Group in western Oregon: geologic structures and other factors that controlled flow emplacement patterns. In Volcanism and

Tectonism in the Columbia River Flood-Basalt Province, SP Reidel and PR Hooper (eds), Special Paper 239, pp. 223-246. Geological Society of America, Boulder, Colorado.

Bentley RD, JL Anderson, NP Campbell, and DA Swanson. 1980. Stratigraphy and Structure of the Yakima Indian Reservation, with Emphasis on the Columbia River Basalt Group. Open-File Report 80200, U.S. Geological Survey, Reston, Virginia.

Berberian M. 1995. Master "blind” thrust faults hidden under the Zagros folds: active basement tectonics and surface morphotectonics. Tectonophysics 241:193-224.

Bjornstad BN, K Winsor, and SD Unwin. 2012. A Summary of Fault Recurrence and Strain Rates in the Vicinity of the Hanford Site - Topical Report. PNNL-17497, Pacific Northwest National Laboratory, Richland, Washington.

Bruhn RL. 1981. Preliminary Analysis of Deformation in Part of the Yakima Fold Belt: South-Central Washington. Department of Geology and Geophysics, University of Utah, Salt Lake City.

Budnitz RJ, G Apostolakis, DM Boore, LS Cluff, KJ Coppersmith, CA Cornell, and PA Morris. 1997. Recommendations for Probabilistic Seismic Hazard Analysis: Guidance on Uncertainty and Use of Experts. NUREG/CR-6372, U.S. Nuclear Regulatory Commission, Washington, D.C.

Campbell NP. 1988. Structural Geology Along the Northwestern Columbia River Basalt Margin, Washington. Open File Report 88-5, Geology and Earth Resources Division, Washington State Department of Natural Resources, Olympia.

Campbell NP. 1989. Structural and stratigraphic interpretation of rocks under the Yakima fold belt, Columbia Basin, based on recent surface mapping and well data. In Volcanism and Tectonism in the Columbia River Flood-Basalt Province, SP Reidel and PR Hooper (eds), Special Paper 239, pp. 209-222. Geological Society of America, Boulder, Colorado.

Campbell NP and RD Bentley. 1981. Late Quaternary deformation of the Toppenish Ridge uplift in south-central Washington. Geology 9:519-524.

Campbell NP, T Ring, and T Repasky. 1995. Earthquake hazard study in the vicinity of Toppenish Basin, south-central Washington. In National Earthquake Hazards Reduction Program Annual Project Summaries: XXXVI - Volume I, ML Jacobson (comp), Open-File Report 95-210, pp. 291-306. U.S. Geological Survey, Menlo Park, California.

Chamness MA and TL Tolan. 1983. Status Report on the Tectonic Fracture and Breccia Study in the Vantage Area. SD-BWI-ER-005, Rockwell Hanford Operations, Richland, Washington.

Cheney ES. 2003. Regional Tertiary sequence stratigraphy and regional structure on the eastern flank of the central Cascade Range, Washington. In Western Cordillera and Adjacent Areas, TW Swanson (ed), GSA Field Guide 4, pp. 177-199. Geological Society of America, Boulder, Colorado. 
Cowan DS. 1981. The Origin of the Umtanum Ridge-Gable Mountain Structural Trend and Implications for a Regional Tectonic Model. Skagit/Hanford Nuclear Project Preliminary Safety Analysis Report Amendment 23, Appendix 2S. Puget Sound Power and Light, Kirkland, Washington.

Crider JG, RS Crosson, and J Brooks. 2003. The Chelan seismic zone, the Great Terrace and the December 1872 Washington State earthquake. Abstracts with Programs 35:645, Geological Society of America, Boulder, Colorado.

Davis, GA. 1977. Tectonic Evolution of the Pacific Northwest: Precambrian to Present. WNP 1/4 Preliminary Safety Analysis Report Amendment 23, Appendix 2R C, Washington Public Power Supply System, Richland, Washington.

Finnegan NJ and DR Montgomery. 2003. Geomorphic and seismic evidence for recent deformation in the Yakima Fold Belt between Ellensburg and Yakima, WA. Abstracts with Programs 35:512, Geological Society of America, Boulder, Colorado.

Geomatrix. 1996. Probabilistic Seismic Hazard Analysis, DOE Hanford Site, Washington. WHC-SDW236A-TI-002, Rev. 1, Westinghouse Hanford Company, Richland, Washington.

Hooper PR and RM Conrey. 1989. A model for the tectonic setting of the Columbia River Basalt eruptions. In Volcanism and Tectonism in the Columbia River Flood-Basalt Province, SP Reidel and PR Hooper (eds), Special Paper 239, pp. 239-306. Geological Society of America, Boulder, Colorado.

Jarchow CM, RD Catchings, and WJ Lutter. 1994. Large-explosive source, wide-recording aperture, seismic profiling on the Columbia Plateau, Washington. Geophysics 59(2):259-271.

Johnson PA. 1989. Central Washington seismicity: evidence for a reactivated buried continental rift and northwest-trending structural zones. Geophysical Research Letters. 11:1325-1328.

Lacombe S, F Mouthereau, S Kargar, and B Meyer. 2006. Late Cenozoic and modern stress fields in the western Fars (Iran): Implications for the tectonic and kinematic evolution of central Zagros. Tectonics 25:TC1003.

Last GV, K Winsor, and SD Unwin. 2012. A Summary of Information on the Behavior of the Yakima Fold Belt as a Structural Entity - Topical Report. PNNL-17471, Pacific Northwest National Laboratory, Richland, Washington.

Laubscher HP. 1981. Models of the Development of Yakima Deformation. WNP 2 Final Safety Analysis Report Amendment 18, Appendix 2.5-O, Washington Public Power Supply System, Richland, Washington.

Lutter WJ, RD Catchings, and CM Jarchow. 1994. An image of the Columbia Plateau from inversion of high-resolution seismic data. Geophysics 59(8):1278-1289.

Mann GM and CE Meyer. 1993. Late Cenozoic structure and correlations to seismicity along the Olympic-Wallowa lineament, northwest United States. Geological Society of America Bulletin 105:853871.

McCaffrey R, AI Qamar, RW King, R Wells, G Khazaradze, CA Williams, CW Stevens, JJ Vollick, and PC Zwick. 2007. Fault locking, block rotation and crustal deformation in the Pacific Northwest. Geophysical Journal International 169(3):1315-1340. 
Mège D and RE Ernst. 2001. Contractional effects of mantle plumes on Earth, Mars, and Venus. In Mantle Plumes: Their Identification Through Time, RE Ernst and KL Buchanan (eds), Special Paper 352, pp. 103-140. Geological Society of America, Boulder, Colorado.

Miner A. 2002. Eocene Tectonics and Active Deformation in Cascadia. MS thesis, Central Washington University, Ellensburg.

Montgomery SL. 2008. New exploration concepts highlight Columbia River basin's potential. Oil and Gas Journal 106(2):35-42.

Price EH. 1982. Structural Geometry, Strain Distribution, and Mechanical Evolution of Eastern Umtanum Ridge and a Comparison with Other Selected Localities Within Yakima Fold Structures, SouthCentral Washington. RHO-BWI-SA-138, Rockwell Hanford Operations, Richland, Washington.

Price EH and AJ Watkinson. 1989. Structural geometry and strain distribution within aastern Umtanum fold ridge, south-central Washington. In Volcanism and Tectonism in the Columbia River Flood-Basalt Province, SP Reidel and PR Hooper (eds), Special Paper 239, pp. 283-292. Geological Society of America, Boulder, Colorado.

PSPL (Puget Sound Power and Light Company). 1981. Skagit/Hanford Nuclear Project, Preliminary Safety Analysis Report. Puget Sound Power and Light Company, Kirkland, Washington.

Reidel SP. 1984. The Saddle Mountains: the evolution of an anticline in the Yakima Fold Belt. American Journal of Science 284(8):942-978.

Reidel SP, NP Campbell, KR Fecht, and KA Lindsey. 1994. Late Cenozoic structure and stratigraphy of south-central Washington. In Regional Geology of Washington, ES Cheney and R Lasmanis (eds), Washington Division of Geology and Earth Resources Bulletin 80, pp. 159-180. Washington State Department of Natural Resources, Division of Geology and Earth Resources, Olympia.

Reidel SP, KR Fecht, MC Hagood, and TL Tolan. 1989. The geologic evolution of the central Columbia Plateau. In Volcanism and Tectonism in the Columbia River Flood-Basalt Province, SP Reidel and PR Hooper (eds), Special Paper 239, pp. 247-264. Geological Society of America, Boulder, Colorado.

Reidel SP, J Kauffman, D Garwood, and J Bush. 2006. What lies below the Columbia River basalt? Eos, Transactions, American Geophysical Union 87(52), Fall Meeting Supplement, Abstract T21B-0422.

Reidel SP, J Bush, D Garwood, J Kauffman, and BS Martin. 2005. The tectonic evolution of the northern Columbia River flood basalt province. Abstracts with Programs 37(7):126, Geological Society of America, Boulder, Colorado.

Reidel SP and NP Campbell. 1989. Guide to the structure of the Yakima Fold Belt. In Field Trips for the Geological Society of America Cordilleran and Rocky Mountain Sections Joint Meeting, Spokane, Washington, N Joseph (ed), Circular 86 (geologic guidebook for Washington and adjacent areas), pp. 275-304. Washington State Department of Natural Resources, Division of Geology and Earth Resources, Olympia.

Reidel SP and TL Tolan. 1994. Late Cenozoic structure and correlations to seismicity along the Olympic-Wallowa Lineament, northwestern United States: Discussion. Geological Society of America Bulletin 106:1634-1638.

Reidel SP and TL Tolan. 2007. The Columbia River Basalt Group volcanism in the Blue Mountains, a middle Miocene reference datum for structural analysis. Abstracts with Programs 39(6):290. Geological Society of America, Boulder, Colorado. 
Rohay AC and JD Davis. 1983. Contemporary deformation in the Pasco Basin area of the central Columbia Plateau. In Preliminary Interpretation of the Tectonic Stability of the Reference Repository Location, Cold Creek Syncline, JA Caggiano and DW Duncan (eds), pp. 6-1-6.29. RHO-BW-ST-19P, Rockwell Hanford Operations, Richland, Washington.

Rohay AC, MD Sweeney, DC Hartshorn, RE Clayton, and JL Devary. 2007. Annual Hanford Seismic Report for Fiscal Year 2007. PNNL-17183, Pacific Northwest National Laboratory, Richland, Washington.

Saltus RW. 1993. Upper-crustal structure beneath the Columbia River Basalt Group, Washington: gravity interpretation controlled by borehole and seismic studies. Geological Society of America Bulletin, 5:1247-1259.

Swanson DA, JL Anderson, RD Bentley, GR Byerly, VE Camp, JN Gardner, and TL Wright. 1979. Reconnaissance Geologic Map of the Columbia River Basalt Group in Eastern Washington and Northern Idaho. Open-File Report 79-1363, U.S. Geological Survey, Reston, Virginia.

Tabor RW, VA Frizzell Jr., DB Booth, and RB Waitt. 2000. Geologic map of the Snoqualmie Pass $30 \mathrm{x}$ 60 minute quadrangle, Washington (scale 1:100,000). Geologic Investigations Series Map I-2538, U.S. Geological Survey, Reston, Virginia.

Tabor RW, VA Frizzell Jr., JA Vance, and CW Naeser. 1984. Ages and stratigraphy of lower and middle Tertiary sedimentary and volcanic rocks of the central Cascades, Washington: Application to the tectonic history of the Straight Creek fault. Geological Society of America Bulletin 95:26-44.

Tolan TL and SP Reidel. 1989. Structure map of a portion of the Columbia River flood-basalt province (scale 1:500,000). In Volcanism and Tectonism in the Columbia River Flood-Basalt Province, SP Reidel and PR Hooper (eds), Special Paper 239. Geological Society of America, Boulder, Colorado.

Watters TR. 1989. Periodically spaced anticlines of the Columbia Plateau. In Volcanism and Tectonism in the Columbia River Flood-Basalt Province, SP Reidel and PR Hooper (eds), Special Paper 239, pp. 283-292. Geological Society of America, Boulder, Colorado.

Wells RE and RW Simpson. 2001. Microplate motion of the Cascadia forearc and implications for subduction deformation. Earth, Planets and Space 53:275-283.

Yeats RS. 1986. Active faults related to folding. Chapter 4 in Active Tectonics: Impact on Society, Geophysics Study Committee, Geophysics Research Forum, National Research Council, pp. 63-79. The National Academies Press, Washington, D.C.

Zachariasen J, S Olig, I Wong, and RS Yeats. 2006. Technical Review of the Seismic Source Model for the Yakima Fold Belt. URS Corporation, Oakland, California. 


\section{Appendix A}

Identification of Topical Reports to Be Prepared for the Future Hanford Site-Wide Probabilistic Seismic Hazard Analysis 



\title{
Appendix A
}

\section{Identification of Topical Reports to Be Prepared for the Future Hanford Site-Wide Probabilistic Seismic Hazard Analysis}

\author{
August 7, 2007
}

\section{A.1 Background}

A series of topical reports will be prepared as a resource to conducting a future probabilistic seismic hazard analysis (PSHA) of the Hanford Site. These topical reports will focus on technical issues that satisfy both following criteria:

1. It is an issue that is important to the seismic hazard. That is, the sensitivity of the calculated seismic hazard to the specific resolution of the issue is significant. Equivalently, uncertainty in the appropriate resolution of the issue results in a significant contribution to the total uncertainty in the estimate of the seismic hazard.

2. The correct resolution of the issue is a matter of contention in the expert community. That is, there are opposing schools of thought on the correct resolution, in contrast to a situation in which there is broad agreement that the correct resolution is uncertain.

The purpose of the topical reports is to summarize the range of opinions expressed by the expert community and to encapsulate the data and publications that support those opinions.

For a PSHA performed in conformance with Senior Seismic Hazard Analysis Committee (SSHAC) Study Level 2 or 3 (as in the case of the future Hanford Site PSHA), it is the function of the technical integrator (TI) to identify appropriate models and, in light of opinions expressed by the expert community, develop a probabilistic characterization of the aleatory variabilities and epistemic uncertainties associated with the models and their quantifications. The topical reports are not intended to resolve the technical issues they address but rather to provide clear expressions of the issues to the TIs, the TI teams, and the subject matter experts assembled to support the PSHA. Further, they provide a summary and compilation of all applicable data and information that pertain to the issues.

Here we identify the topical reports that will be developed as a resource to the future Hanford sitewide PSHA. The areas to be addressed in the topical reports were selected during a meeting of July 12, 2007, involving the following participants:

- Tom Brouns, PNNL

- Ken Buxton, PNNL

- Kevin Coppersmith, Coppersmith Consulting

- Steve Reidel, Washington State University

- Alan Rohay, PNNL

- Steve Unwin, PNNL. 
The principal resource supporting the deliberations of this group was a report prepared by Kevin Coppersmith, Coppersmith Consulting, in which issues and data needs for a future PSHA were identified and evaluated (draft report of June 11, 2007). For convenience, the tabulation of issues from the Coppersmith report is included in this appendix as Table A.1. This table identifies technical issues related both to seismic source characterization (SSC) and to the analysis of ground motion attenuation (GMA).

\section{A.2 Conclusions}

With respect to the selection criteria identified previously, the following conclusions were drawn:

\section{A.2.1 Seismic Source Characterization}

Based on review of the SSC issues identified in Table A.1, the recommendation is to prepare topical reports addressing the following issues:

- SSC Issue 1: use of coupled versus uncoupled fault models - This issue is assessed to have a High level of contention with Moderate potential for impact on hazard estimation.

- SSC Issue 6: whether observation of activity along one Yakima fold structure should be considered an indicator of behavior along all Yakima fold structures - This topic is assessed to have a High level of contention with up to Moderate potential for impact on the hazard estimate.

- SSC Issue 7: whether slip rates should be greater than those used in the previous Hanford PSHA, which were based on post-Columbia River Basalt Group ages - This topic is assessed to be Moderately contentious with up to High potential for impact on the hazard estimation.

\section{A.2.2 Ground Motion Attenuation}

While the issue of using next generation attenuation (NGA) models could potentially have a high impact on the mean hazard and hazard uncertainty estimates, there is not a high level of contention associated with this or any of the GMA-related issues. Therefore, none of the topical reports will focus on GMA issues.

In addition to the three recommended topical reports identified above, an annotated bibliography of reports and data relevant to all SSC and GMA issues will be assembled, along with copies of all reports for use by the TIs, peer reviewers, and experts. 
Table A.1. Hanford Seismic Records and Scoping Analysis Issues and Data Needs (from Coppersmith Consulting, June 11, 2007)

\begin{tabular}{|c|c|c|c|c|}
\hline Issue $^{(a)}$ & Importance to Hazard $^{(\mathrm{b})}$ & $\begin{array}{c}\text { Level of } \\
\text { Contention }^{(\mathrm{c})}\end{array}$ & $\begin{array}{l}\text { Types of Data Needed to } \\
\text { Address for PSHA }\end{array}$ & Existing Data ${ }^{(\mathrm{e})}$ \\
\hline \multicolumn{5}{|c|}{ Seismic Source Characterization Issues } \\
\hline $\begin{array}{l}\text { 1. Greater weight should be } \\
\text { given to the coupled model } \\
\text { Uncoupled model means } \\
\text { smaller downdip extent, } \\
\text { smaller Mmax and source-site } \\
\text { distance } \\
\text { Coupling: preference for } \\
\text { uncoupled model is not } \\
\text { supported } \\
\text { - Several lines of evidence } \\
\text { suggest that YFB structures } \\
\text { are related to basement } \\
\text { structures or could be traced to } \\
\text { basement structures } \\
\text { Lateral extent of Yakima fold } \\
\text { structures to east and to west } \\
\text { of CRB is uncertain }\end{array}$ & $\begin{array}{l}\text { Moderate: increased rupture } \\
\text { area for larger Mmax (lower } \\
\text { hazard) and larger moment } \\
\text { rate (higher hazard); } \\
\text { perhaps differences in } \\
\text { source to site distance }\end{array}$ & High & $\begin{array}{l}\text { Deep geophysical data (reflection and } \\
\text { refraction) } \\
\text { - } \quad \text { High-resolution instrumental } \\
\text { seismicity (hypocenter distributions, } \\
\text { focal mechanisms } \\
\text { - } \quad \text { Comparisons of locations of basement } \\
\text { and basalt structures } \\
\text { - Analysis of lateral extent of fold } \\
\text { structures into adjacent domains } \\
\text { Evidence for large single-event } \\
\text { displacements }\end{array}$ & $\begin{array}{l}\text { Rohay and Davis } 1983 \\
\text { Catchings and Mooney } 1988 \\
\text { Ludwin et al. } 1991 \\
\text { Tolan et al. } 2004 \\
\text { Garwood et al. 2003 } \\
\text { Reidel and Campbell } 1989 \\
\text { Campbell 1988, } 1989 \\
\text { Mann and Meyer } 1993 \\
\text { Lidke et al. 2003 } \\
\text { Reidel et al. 1989 } \\
\text { Beeson and Moran } 1979 \\
\text { Tolan 1982 } \\
\text { Tolan and Beeson } 1984 \\
\text { Tabor et al. 1982, } 1984 \\
\text { Tabor et al. 2000 } \\
\text { Reidel 1984 } \\
\text { Yeats et al. 1997 } \\
\text { Berberian 1981, } 1995 \\
\text { Ni and Barazangi } 1986 \\
\text { Lacombe et al. 2006 }\end{array}$ \\
\hline 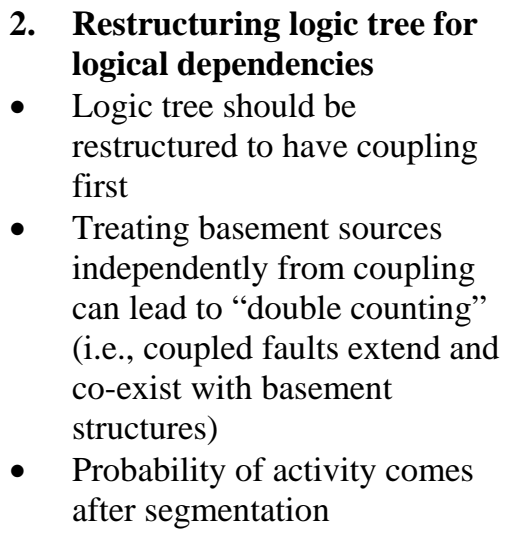 & & & & \\
\hline
\end{tabular}




\begin{tabular}{|c|c|c|c|c|}
\hline Issue $^{(a)}$ & Importance to Hazard $^{(\mathrm{b})}$ & $\begin{array}{c}\text { Level of } \\
\text { Contention }\end{array}$ & $\begin{array}{l}\text { Types of Data Needed to } \\
\text { Address for PSHA }{ }^{(\mathrm{d})}\end{array}$ & Existing Data $^{(\mathrm{e})}$ \\
\hline \multicolumn{5}{|c|}{ Seismic Source Characterization Issues } \\
\hline $\begin{array}{l}\text { Fault activity should be } \\
\text { considered together with } \\
\text { coupling, since faults rooted in } \\
\text { the basement are more likely } \\
\text { to be active }\end{array}$ & $\begin{array}{l}\text { Low to moderate: If leads to } \\
\text { higher probability of } \\
\text { activity, hazard will increase } \\
\text { for nearby folds }\end{array}$ & $\begin{array}{l}\text { Moderate to } \\
\text { High }\end{array}$ & $\begin{array}{l}\text { - Analysis; no new data (see data needs } \\
\text { for probability of activity below) }\end{array}$ & \\
\hline $\begin{array}{l}\text { 3. Evidence of activity on YFB } \\
\text { structures may be difficult to } \\
\text { recognize } \\
\text { - } \text { Large Quaternary fault } \\
\text { ruptures could be present on } \\
\text { many Yakima folds, but could } \\
\text { be broadly distributed, blind } \\
\text { faulting, or obscured in the } \\
\text { Quaternary record due to low } \\
\text { rates } \\
\text { Absence of surface expression } \\
\text { of primary slip does not } \\
\text { preclude activity on } \\
\text { subsurface fault }\end{array}$ & $\begin{array}{l}\text { Low to moderate: If leads to } \\
\text { higher probability of } \\
\text { activity, hazard will increase } \\
\text { for nearby folds }\end{array}$ & $\begin{array}{l}\text { Moderate to } \\
\text { High }\end{array}$ & $\begin{array}{l}\text { Detailed maps of Quaternary deposits } \\
\text { (including Touchet beds) and their } \\
\text { distribution relative to folds for signs } \\
\text { of uplift or deformation } \\
\text { - Geomorphic analysis of Quaternary } \\
\text { surfaces for evidence of distributed } \\
\text { faulting, tilting } \\
\text { - Analysis of high resolution } \\
\text { instrumental seismicity and focal } \\
\text { mechanisms for 3-d distribution of } \\
\text { fault planes and potential for blind } \\
\text { faulting }\end{array}$ & $\begin{array}{l}\text { Yeats } 1986 \\
\text { Yeats et al. } 1997 \\
\text { Lidke et al. } 2003 \\
\text { Bentley et al. } 1980 \\
\text { Campbell and Bentley } 1981 \\
\text { Campbell et al. 1995 } \\
\text { Repasky and Campbell } 1998 \\
\text { West and Shaffer } 1988 \\
\text { West et al. } 1996 \\
\text { West } 1998 \\
\text { S. Personius } 2006 \\
\text { Rigby and Othberg } 1979 \\
\text { Piety et al. 1990 } \\
\text { Sandness et al. 1982 } \\
\text { Finnegan and Montgomery } \\
2003\end{array}$ \\
\hline $\begin{array}{l}\text { 4. Instrumental seismicity data } \\
\text { are not reliable indicators of } \\
\text { future activity } \\
\text { - Instrumental seismicity is not } \\
\text { long enough to illuminate fault } \\
\text { planes }\end{array}$ & $\begin{array}{l}\text { Low to moderate: one of } \\
\text { several criteria for assessing } \\
\text { the activity of folds; } \\
\text { hypocentral distribution } \\
\text { sheds light on seismogenic } \\
\text { behavior of basalts, } \\
\text { sediments, basement }\end{array}$ & Moderate & $\begin{array}{l}\text { - Comprehensive catalog of all } \\
\text { historical and instrumental events } \\
\text { - Focal mechanisms and depth } \\
\text { distributions for well-resolved events }\end{array}$ & $\begin{array}{l}\text { Reidel et al. } 1994 \\
\text { Rohay and Davis } 1983 \\
\text { Rohay } 2003 \\
\text { Ludwin et al. } 1991 \\
\text { Miner 2002a, b } \\
\text { Finnegan and Montgomery } \\
2003 \\
\text { Crider et al. } 2003 \\
\text { Bakun et al. } 2002\end{array}$ \\
\hline
\end{tabular}




\begin{tabular}{|c|c|c|c|c|}
\hline Issue $^{(a)}$ & Importance to Hazard $^{(\mathrm{b})}$ & $\begin{array}{c}\text { Level of } \\
\text { Contention }\end{array}$ & $\begin{array}{l}\text { Types of Data Needed to } \\
\text { Address for PSHA }\end{array}$ & Existing Data $^{(\mathrm{e})}$ \\
\hline \multicolumn{5}{|c|}{ Seismic Source Characterization Issues } \\
\hline $\begin{array}{l}\text { 5. Large historical earthquakes } \\
\text { and paleoseismologic } \\
\text { evidence have not been } \\
\text { considered } \\
\text { 1872 Lake Chelan EQ M } 6.8 \\
\text { and ongoing seismicity zone } \\
\text { consistent with blind thrust } \\
\text { faulting and looks like YFB } \\
\text { - } \quad \text { Clastic dikes and sills could be } \\
\text { liquefaction features from } \\
\text { shaking } \\
\text { - Touchet beds could be used } \\
\text { for assessing fold deformation } \\
\end{array}$ & $\begin{array}{l}\text { Low to Moderate: Some } \\
\text { effect on Mmax; possibly } \\
\text { recurrence; not source- } \\
\text { specific (this is data related } \\
\text { to prehistorical shaking } \\
\text { effects) }\end{array}$ & $\begin{array}{l}\text { Moderate to } \\
\text { High (USGS } \\
\text { has focused } \\
\text { on } 1872 \\
\text { earthquake) }\end{array}$ & $\begin{array}{l}\text { - Studies of intensity distributions for } \\
\text { historical earthquakes } \\
\text { - Field studies of locations of } \\
\text { prehistorical shaking effects } \\
\text { (paleoliquefaction, disturbed lake } \\
\text { sediments) } \\
\text { - Maps of intensity and paleo-intensity } \\
\text { to assess possible causative source(s) }\end{array}$ & $\begin{array}{l}\text { Fecht et al. } 1999 \\
\text { I. Madin pers. comm. } 2006 \\
\text { Bakun et al. } 2002 \\
\text { Crider et al. } 2003\end{array}$ \\
\hline $\begin{array}{l}\text { 6. Observations of activity } \\
\text { along one fold structure } \\
\text { should be indicator of } \\
\text { behavior along all fold } \\
\text { structures } \\
\text { - Mapped normal faults that } \\
\text { suggest deeper faulting on } \\
\text { Toppenish and Horse Heaven } \\
\text { could be present on other } \\
\text { faults as well; No clear basis } \\
\text { for concluding that these folds } \\
\text { are different that all other } \\
\text { Yakima folds } \\
\text { Evidence for Quaternary } \\
\text { deformation distributed } \\
\text { throughout the fold belt means } \\
\text { that most and perhaps all of } \\
\text { the fold structures are likely } \\
\text { active } \\
\text { Evidence at Toppenish Ridge, } \\
\text { Saddle Mtn and Ahtanum } \\
\text { means is }\end{array}$ & & High & $\begin{array}{l}\text { - Structural and tectonic models of } \\
\text { YFB, including kinematics and timing } \\
\text { of deformation throughout the } \\
\text { province } \\
\text { - Comparison of YFB to appropriate } \\
\text { analogues to assess potential for } \\
\text { differences in activity among } \\
\text { structures } \\
\text { - } \text { [Note: all data related to assessment of } \\
\text { activity will be applicable to this } \\
\text { assessment] }\end{array}$ & $\begin{array}{l}\text { Bentley et al. } 1980 \\
\text { Campbell and Bentley } 1981 \\
\text { Campbell et al. 1995 } \\
\text { Repasky and Campbell } 1998 \\
\text { West and Shaffer } 1988 \\
\text { West et al. 1994,1996 } \\
\text { West 1997 } \\
\text { S. Personius written comm. } \\
2006 \\
\text { WPPSS } 1982 \\
\text { Reidel et al. } 1994 \\
\text { Grolier and Bingham } 1971 \\
\text { West and Shaffer 1988 } \\
\text { Shaffer and West 1989 } \\
\text { Farooqui and Thoms } 1980 \\
\text { Kienle et al. 1979 } \\
\text { Reidel et al. } 1994 \\
\text { McQuarrie 1993 } \\
\text { Piety et al. 1990 } \\
\text { Foundation Sciences } 1980 \\
\text { Anderson and Tolan } 1986\end{array}$ \\
\hline
\end{tabular}




\begin{tabular}{|c|c|c|c|c|}
\hline Issue $^{(a)}$ & Importance to Hazard $^{(\mathrm{b})}$ & $\begin{array}{c}\text { Level of } \\
\text { Contention }\end{array}$ & $\begin{array}{l}\text { Types of Data Needed to } \\
\text { Address for PSHA }\end{array}$ & Existing Data $^{(\mathrm{e})}$ \\
\hline \multicolumn{5}{|c|}{ Seismic Source Characterization Issues } \\
\hline $\begin{array}{l}\text { o } \begin{array}{l}\text { representative of the } \\
\text { entire fold belt }\end{array} \\
\text { o Geomorphic evidence of } \\
\text { Quaternary deformation } \\
\text { at Yakima Ridge, } \\
\text { Umtanum Ridge, and } \\
\text { HHH } \\
\text { YFB is single structural entity, } \\
\text { so folds scattered throughout } \\
\text { the fold belt are active and the } \\
\text { rest are therefore active }\end{array}$ & $\begin{array}{l}\text { Low to moderate: If leads to } \\
\text { higher probability of } \\
\text { activity, hazard will increase } \\
\text { for nearby folds }\end{array}$ & & & $\begin{array}{l}\text { Reidel et al. } 1994 \\
\text { Lidke et al. 2003 } \\
\text { Lidke 2002a-d, 2003a-e } \\
\text { Lidke and Bucknam 2002,2003 } \\
\text { Personius and Lidke 2003a-d } \\
\text { Beanland and Berryman 1989 } \\
\text { Yeats 1986 } \\
\text { Reidel 1984 } \\
\text { Reidel and Campbell 1989 } \\
\text { Finnegan and Montgomery } \\
2003 \\
\text { WPPSS 1982 } \\
\text { Reidel and Fecht 1994 } \\
\text { Schuster et al.1997 } \\
\text { Rigby and Othberg } 1979 \\
\text { Sandness et al. 1982 } \\
\text { Hemphill-Haley } 1999 \\
\text { Mann and Meyer 1993 } \\
\text { Wong et al. } 2002 \\
\text { Kuehn 1995 } \\
\text { Glass 1977 } \\
\text { Walsh et al. } 1997\end{array}$ \\
\hline $\begin{array}{l}\text { 7. Recurrence rates may be } \\
\text { higher than estimated using } \\
\text { post-CRB ages } \\
\text { Geodetic rates of N-S } \\
\text { contraction could be as high as } \\
2 \mathrm{~mm} / \mathrm{yr} \\
\text { o Could use geodetic data } \\
\text { to characterize } \\
\text { deformation rates of } \\
\text { crustal seismic sources } \\
\text { Not enough uncertainty in slip rate: } \\
\text { geodetic and rates from those folds } \\
\text { well-studied }\end{array}$ & & & $\begin{array}{l}\text { - Fold/fault-specific Quaternary slip rate } \\
\text { estimates, based on observed } \\
\text { displacements } \\
\text { - Slip rate estimates based on } \\
\text { deformation (uplift, tilt, folding) of } \\
\text { Quaternary deposits and/or } \\
\text { geomorphic analysis } \\
\text { - Fold/fault-specific paleoseismic data } \\
\text { on recurrence intervals for surface } \\
\text { rupturing or surface deforming events } \\
\text { - High-resolution geodetic data } \\
\text { - Information [see issue above] } \\
\text { suggesting that recurrence rate }\end{array}$ & $\begin{array}{l}\text { West et al. } 1996 \\
\text { West } 1997 \\
\text { Prescott and Savage } 1984 \\
\text { Savage et al. } 1981 \\
\text { Miller et al. } 2001 \\
\text { Miller and Johnson } 2002 \\
\text { Ning and Qamar } 2003 \\
\text { McCaffrey } 2002 \\
\text { McCaffrey written comm. } 2006 \\
\text { T. Melbourne } 2006 \\
\text { W. Thatcher written comm. } \\
\text { 2006 } \\
\text { Reidel et al. } 1994 \\
\text { Reidel } 1984\end{array}$ \\
\hline
\end{tabular}




\begin{tabular}{|c|c|c|c|c|}
\hline Issue $^{(a)}$ & Importance to Hazard $^{(\mathrm{b})}$ & $\begin{array}{c}\text { Level of } \\
\text { Contention }^{(\mathrm{c})}\end{array}$ & $\begin{array}{l}\text { Types of Data Needed to } \\
\text { Address for PSHA }\end{array}$ & Existing Data $^{(\mathrm{e})}$ \\
\hline \multicolumn{5}{|c|}{ Seismic Source Characterization Issues } \\
\hline $\begin{array}{l}\text { (Toppenish and Ahtanum) } \\
\text { could be used for the other } \\
\text { folds as well }\end{array}$ & $\begin{array}{l}\text { Moderate to High: hazard } \\
\text { results vary linearly with } \\
\text { recurrence rate }\end{array}$ & $\begin{array}{l}\text { Low to } \\
\text { Moderate }\end{array}$ & $\begin{array}{l}\text { information on single structure in } \\
\text { province can be used for other } \\
\text { structures in province }\end{array}$ & $\begin{array}{l}\text { Reidel et al. } 1989 \\
\text { Bentley et al. } 1980 \\
\text { Campbell and Bentley } 1981 \\
\text { Campbell et al. } 1995 \\
\text { Repasky and Campbell } 1998\end{array}$ \\
\hline $\begin{array}{l}\text { 8. Nature of the basement } \\
\text { rocks } \\
\text { - Assumed basement rocks are } \\
\text { crystalline, but may be } \\
\text { Mesozoic continental-margin } \\
\text { rocks } \\
\text { o Reference made to core in } \\
\text { Darcell oil-exploratory } \\
\text { well (S.P. Reidel pers. } \\
\text { Comm. 2006) }\end{array}$ & $\begin{array}{l}\text { Low: could affect } \\
\text { assessments of maximum } \\
\text { seismogenic depth, } \\
\text { dimensions of structures in } \\
\text { basement }\end{array}$ & Low & $\begin{array}{l}\text { - Deep drilling data and/or deep } \\
\text { geophysics } \\
\text { - Geologic interpretations of } \\
\text { comparable rocks in adjacent domains } \\
\text { to east and west }\end{array}$ & $\begin{array}{l}\text { Catchings and Mooney } 1988 \\
\text { S.P. Reidel, pers. comm. to } \\
\text { R. Yeats } 2006\end{array}$ \\
\hline \multicolumn{5}{|c|}{ Ground Motion Attenuation Issues } \\
\hline $\begin{array}{l}\text { 9. } \begin{array}{l}\text { Many existing applicable } \\
\text { ground motion models will } \\
\text { be superceded by PEER } \\
\text { Next Generation Attenuation } \\
\text { models }\end{array} \\
\text { The NGA models should be } \\
\text { available in time for this } \\
\text { PSHA; the PEER reports will } \\
\text { be completed and a special } \\
\text { issue of Spectra is being } \\
\text { developed (final papers due } \\
\text { July?) }\end{array}$ & $\begin{array}{l}\text { Moderate to High: GM } \\
\text { attenuation is typically } \\
\text { largest contributor to mean } \\
\text { hazard and to total hazard } \\
\text { uncertainty }\end{array}$ & Moderate & $\begin{array}{ll}- & \text { Will need final suite of NGA } \\
\text { models }{ }^{(f)}, \text { including discussions of } \\
\text { applicability for non-California site } \\
\text { conditions }\end{array}$ & $\begin{array}{l}\text { Boore and Atkinson } 2006 \\
\text { Campbell and Bozorgnia } 2006 \\
\text { Chiou and Youngs } 2006 \\
\text { Idriss } 2007\end{array}$ \\
\hline
\end{tabular}




\begin{tabular}{|c|c|c|c|c|}
\hline Issue $^{(a)}$ & Importance to Hazard $^{(b)}$ & $\begin{array}{c}\text { Level of } \\
\text { Contention }^{(\mathrm{c})}\end{array}$ & $\begin{array}{l}\text { Types of Data Needed to } \\
\text { Address for PSHA }{ }^{(\mathrm{d})}\end{array}$ & Existing Data $^{(\mathrm{e})}$ \\
\hline \multicolumn{5}{|c|}{ Ground Motion Attenuation Issues } \\
\hline $\begin{array}{l}\text { 10. The NGA models will be } \\
\text { applicable to CA conditions } \\
\text { and each model will require } \\
\text { transfer function for } \\
\text { application to Hanford } \\
\text { - To use the NGA attenuation } \\
\text { models, a transfer function } \\
\text { from CA conditions to generic } \\
\text { site conditions will need to be } \\
\text { developed }\end{array}$ & Moderate & $\begin{array}{l}\text { Low to } \\
\text { Moderate }\end{array}$ & $\begin{array}{l}\text { Bob Youngs developing this now for } \\
\text { the existing models, but not NGA, for } \\
\text { the WTP at the surface } \\
\text { - Consideration of revisions, if any, } \\
\text { needed from Youngs' work for Vs } 30 \\
\text { or other locations in site profile }\end{array}$ & \\
\hline $\begin{array}{l}\text { 11. The suite of NGA models } \\
\text { will not define the full } \\
\text { epistemic uncertainty, more } \\
\text { will be needed } \\
\text { The USGS will also be } \\
\text { looking at how to use the } \\
\text { NGA models and will } \\
\text { probably define some arbitrary } \\
\text { factor to represent epistemic } \\
\text { uncertainty; this can be } \\
\text { considered in developing the } \\
\text { site model }\end{array}$ & Moderate & Moderate & $\begin{array}{l}\text { - Consideration of other alternative GM } \\
\text { models to span the range of aleatory } \\
\text { variability } \\
\text { - Comparison with epistemic } \\
\text { uncertainties for PSHAs in other } \\
\text { - Consies }\end{array}$ & \\
\hline $\begin{array}{l}\text { 12. } \begin{array}{l}\text { Representative site } \\
\text { conditions will need to be } \\
\text { developed for site-wide }\end{array} \\
\text { application } \\
\text { Develop a reference site } \\
\text { profile (or profiles) that is } \\
\text { representative of the locations } \\
\text { at Hanford where the hazard } \\
\text { assessment will be needed, } \\
\text { including the appropriate } \\
\text { epistemic uncertainty model } \\
\text { (representative site profiles) }\end{array}$ & Moderate & $\begin{array}{l}\text { Low to } \\
\text { Moderate }\end{array}$ & $\begin{array}{l}\text { Identify locations where PSHA may } \\
\text { be applied in the future } \\
\text { Compile data regarding shear wave } \\
\text { velocity structure in upper few } \\
\text { hundred meters } \\
\text { - In absence of site-specific data, use } \\
\text { geologic models to interpret velocity } \\
\text { structure }\end{array}$ & \\
\hline
\end{tabular}




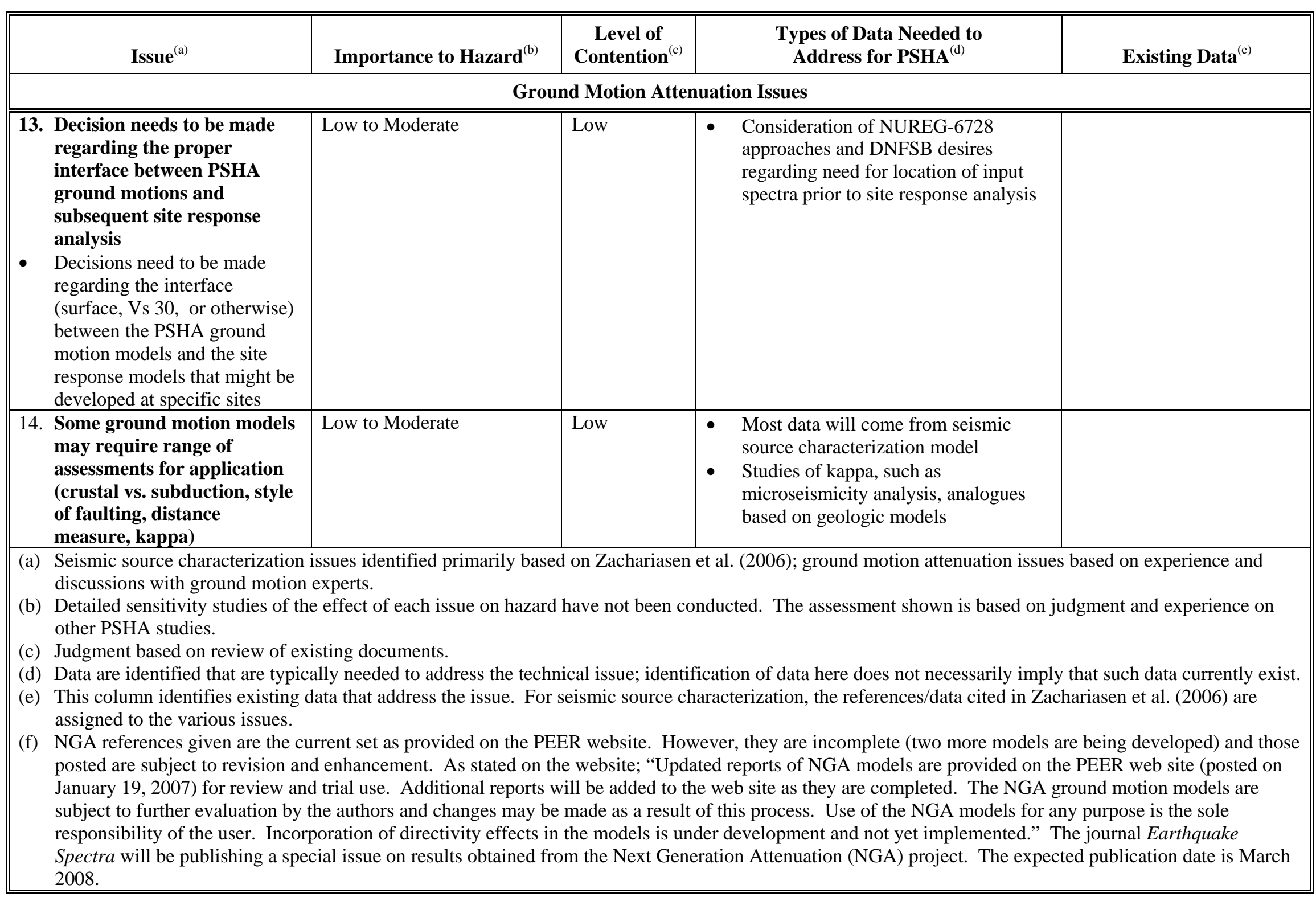




\section{A.3 Sources Cited in Table A.1}

Anderson JL and TL Tolan. 1986. Ages of wrench faulting in interridge basins, southwest Columbia Plateau, Washington and Oregon. Abstracts with Programs 18:82, Geological Society of America, Boulder, Colorado.

Bakun WH, RA Haugerud, MG Hopper, and RS Ludwin. 2002. The December 1872 Washington State earthquake. Bulletin of the Seismological Society of America 92:3239-3258.

Beanland S and KR Berryman. 1989. Style and episodicity of late Quaternary activity on the PisaGrandview Fault Zone, Central Otago, New Zealand. New Zealand Journal of Geology and Geophysics 32:451-461.

Beeson MH and MR Moran. 1979. Columbia River Basalt Group stratigraphy in western Oregon. Oregon Geology 41:11-14.

Bentley RD, JL Anderson, NP Campbell, and DA Swanson. 1980. Stratigraphy and Structure of the Yakima Indian Reservation, with Emphasis on the Columbia River Basalt Group. Open-File Report 80200, U.S. Geological Survey, Reston, Virginia.

Bentley RD, NP Campbell, and JE Powell. 1993. Geologic Maps of Part of the Yakima Fold Belt, Northeastern Yakima County, Washington. Open File Report 93-3, Washington State Department of Natural Resources, Division of Geology and Earth Resources, Olympia.

Bentley RD and NP Campbell. 1983. Geologic map of the Yakima quadrangle, Washington (1 sheet, scale 1:62,500). Map GM-29, Washington State Department of Natural Resources, Division of Geology and Earth Resources, Olympia.

Berberian M. 1981. Active faulting and tectonics of Iran. In Zagros-Hindu-Kush-Himalaya Geodynamic Evolution, HK Gupta and FM Delany (eds), Geodynamic Series 3, pp. 33-69. American Geophysics Union, Washington, D.C.

Berberian M. 1995. Master "blind” thrust faults hidden under the Zagros folds: Active basement tectonics and surface morphotectonics. Tectonophysics 241:193-224.

Boore DM and GM Atkinson. 2006. Boore-Atkinson Provisional NGA Empirical Ground-Motion Model for the Average Horizontal Component of PGA, PGV and SA at Spectral Periods of 0.05, 0.1,0.2, 0.3, 0.5, 1, 2, 3, 4, and 5 seconds. PEER-Lifelines Next Generation Project (Revised 27 October 2006), Pacific Earthquake Engineering Research Center, University of California, Berkeley.

Campbell KW and Y Bozorgnia. 2006. Campbell-Bozorgnia NGA Empirical Ground Motion Model for the Average Horizontal Component of PGA, PGV, PGD and SA at Selected Spectral Periods Ranging from 0.01-10.0 Seconds (Version 1.1). Pacific Earthquake Engineering Research Center, University of California, Berkeley.

Campbell NP. 1983. Correlation of late Cenozoic gravel deposits along the Yakima River drainage from Ellensburg to Richland, Washington. Northwest Science 57:179-193.

Campbell NP. 1988. Structural Geology Along the Northwestern Columbia River Basalt Margin, Washington. Open File Report 88-5, Washington State Department of Natural Resources, Geology and Earth Resources Division, Olympia. 
Campbell NP. 1989. Structural and stratigraphic interpretation of rocks under the Yakima fold belt, Columbia Basin, based on recent surface mapping and well data. In Volcanism and Tectonism in the Columbia River Flood-Basalt Province, SP Reidel and PR Hooper (eds). Special Paper 239, Geological Society of America, Boulder, Colorado.

Campbell NP and RD Bentley. 1981. Late Quaternary deformation of the Toppenish Ridge uplift in south-central Washington. Geology 9:519-524.

Campbell NP, T Ring, and T Repasky. 1995. Earthquake hazard study in the vicinity of Toppenish Basin, south-central Washington. In National Earthquake Hazards Reduction Program Annual Project Summaries: XXXVI - Volume I, ML Jacobson (comp), Open-File Report 95-210, pp. 291-306. U.S. Geological Survey, Menlo Park, California.

Catchings RD and WD Mooney. 1988. Crustal structure of the Columbia Plateau: Evidence for continental rifting. Journal of Geophysical Research 93:459-474.

Chiou BS-J. and RR Youngs. 2006. Chiou and Youngs PEER-NGA Empirical Ground Motion Model for the Average Horizontal Component of Peak Acceleration and Pseudo-Spectral Acceleration for Spectral Periods of 0.01 to 10 Seconds. Pacific Earthquake Engineering Research Center, University of California, Berkeley.

Crider JG, RS Crosson, and J Brooks. 2003. The Chelan seismic zone, the Great Terrace and the December 1872 Washington State earthquake. Abstracts with Programs 35:645, Geological Society of America, Boulder, Colorado.

Farooqui SM and RC Thoms. 1980. Geologic Evaluation of Selected Faults and Lineaments, Pasco and Walla Walla Basins, Southeast Washington. Shannon \& Wilson, Inc., Richland, Washington.

Fecht KR, SP Reidel, and AM Tallman. 1987. Paleodrainage of the Columbia River system on the Columbia Plateau of Washington State - A summary. In Selected Papers on the Geology of Washington, JJ Schuster (ed), Bulletin 77, pp. 219-248. Washington State Department of Natural Resources, Division of Geology and Earth Resources, Olympia.

Fecht KR, KA Lindsey, BN Bjornstad, DG Horton, GV Last, and SP Reidel. 1999. Clastic Injection Dikes of the Pasco Basin and Vicinity. Geologic Atlas Series BHI-01103 Rev. 1, U.S. Department of Energy, Office of Environmental Restoration, Washington, D.C.

Finnegan NJ and DR Montgomery. 2003. Geomorphic and seismic evidence for recent deformation in the Yakima Fold Belt between Ellensburg and Yakima, WA. Abstracts with Programs 35:512, Geological Society of America, Boulder, Colorado.

Foundation Sciences, Inc. 1980. Geologic Reconnaissance of Parts of the Walla Walla and Pullman, Washington, and Pendleton, Oregon $1^{\circ} \times 2^{\circ}$ AMS Quadrangles. U.S. Army Corps of Engineers, Seattle, Washington.

Frankel AD, MD Petersen, CS Muller, KM Haller, RL Wheeler, EV Leyendecker, RL Wesson, SC Harmsen, CH Cramer, DM Perkins, and KS Rukstales. 2002. Documentation for the 2002 Update of the National Seismic Hazard Maps. Open-File Report 02-420, U.S. Geological Survey, Reston, Virginia. 
Garwood DL, JH Bush,, JD Kauffman, and TE Jones. 2003. New interpretations of structures in the Columbia River Basalt Group of the Clearwater Embayment, Idaho. Abstracts with Programs 35:551, Geological Society of America, Boulder, Colorado.

Geomatrix Consultants, Inc. 1988. Seismotectonic Evaluation of the Northern Cascade Mountains Geomorphic Province for Bumping Lake, Tieton, Keechelus, Kachess, Cle Elum, and Clear Creek Dams. Oakland, California.

Geomatrix Consultants, Inc. 1989. Seismotectonic Evaluation, Northwest Rocky Mountains-Okanogan Uplands Geomorphic Province. Oakland, California.

Glass CE. 1977. Remote sensing analysis of the Columbia Plateau. In WPPSS Nuclear Project No. 1, Washington Public Power Supply System Docket No. 50-460: Preliminary Safety Analysis Report, Amendment 23, v. 2B, Appendix 2R, Subappendix 2R K. Preliminary Safety Analysis Report, Washington Public Power Supply System, Richland, Washington.

Grolier MJ and JW Bingham. 1971. Geologic map and sections of parts of Grant, Adams and Franklin counties, Washington (1 sheet, scale 1:62,500). Geology Investigations Map I-589, U.S. Geological Survey, Reston, Virginia.

Hemphill-Haley M. Multi-Scaled Analyses of Contemporary Crustal Deformation of Western North America. Ph.D. dissertation, University of Oregon, Eugene.

Idriss IM. 2007. Empirical Model for Estimating the Average Horizontal Values of Pseudo-Absolute Spectral Accelerations Generated by Crustal Earthquakes Volume 1 Sites with Vs30 $=450$ to $900 \mathrm{~m} / \mathrm{s}$. Pacific Earthquake Engineering Research Center, University of California, Berkeley.

Kienle CF Jr., ML Hamill, and DN Clayton. 1979. Geologic Reconnaissance of the Wallula Gap, Washington-Blue Mountains-La Grande, Oregon Region. Shannon \& Wilson, Inc., Richland, Washington.

Kuehn SC. 1995. The Olympic-Wallowa Lineament, Hite Fault System, and Columbia River Basalt Group Stratigraphy in Northeast Umatilla County, Oregon. M.S. thesis, Washington State University, Pullman.

Lacombe S, F Mouthereau, S Kargar, and B Meyer. 2006. Late Cenozoic and modern stress fields in the western Fars (Iran): Implications for the tectonic and kinematic evolution of central Zagros. Tectonics 25:TC1003.

Lidke DJ. 2002a. Fault number 562a, Saddle Mountains structures, Saddle Mountains fault. In Quaternary Fault and Fold Database of the United States - Version 1.0. Open-File Report 03-417, U.S. Geological Survey, Reston, Virginia. Available at http://qfaults.cr.usgs.gov.

Lidke DJ. 2002b. Fault number 562b, Saddle Mountains structures, folds and other faults of the Saddle Mountains. In Quaternary Fault and Fold Database of the United States - Version 1.0. Open-File Report 03-417, U.S. Geological Survey, Reston, Virginia. Available at http://qfaults.cr.usgs.gov.

Lidke DJ. 2002c. Fault number 563a, Umtanum Ridge structures, Central Gable Mountain fault. In Quaternary Fault and Fold Database of the United States - Version 1.0. Open-File Report 03-417, U.S. Geological Survey, Reston, Virginia. Available at http://qfaults.cr.usgs.gov. 
Lidke DJ. 2002d. Fault number 563b, Umtanum Ridge structures, folds and other faults of the Umtanum Ridge-Gable Mountain uplift. In Quaternary Fault and Fold Database of the United States - Version 1.0. Open-File Report 03-417, U.S. Geological Survey. Available at http://qfaults.cr.usgs.gov.

Lidke DJ. 2003a. Fault number 561a, Frenchman Hills structures, Frenchman Hills fault. In Quaternary Fault and Fold Database of the United States - Version 1.0. Open-File Report 03-417, U.S. Geological Survey, Reston, Virginia. Available at http://qfaults.cr.usgs.gov.

Lidke DJ. 2003b. Fault number 561b, Frenchman Hills structures, Lind Coulee fault. In Quaternary Fault and Fold Database of the United States - Version 1.0. Open-File Report 03-417, U.S. Geological Survey. Available at http://qfaults.cr.usgs.gov.

Lidke DJ. 2003c. Fault number 561c, Frenchman Hills structures, Folds and other faults of the Frenchman Hills uplift. In Quaternary Fault and Fold Database of the United States - Version 1.0. Open-File Report 03-417, U.S. Geological Survey, Reston, Virginia. Available at http://qfaults.cr.usgs.gov.

Lidke DJ. 2003d. Fault number 564a, Ahtanum Ridge structures, Ahtanum Creek fault. In Quaternary Fault and Fold Database of the United States - Version 1.0. Open-File Report 03-417, U.S. Geological Survey, Reston, Virginia. Available at http://qfaults.cr.usgs.gov.

Lidke DJ. 2003e. Fault number 564b, Ahtanum Ridge structures, folds and other faults of the Ahtanum Ridge uplift. In Quaternary Fault and Fold Database of the United States - Version 1.0. Open-File Report 03-417, U.S. Geological Survey, Reston, Virginia. Available at http://qfaults.cr.usgs.gov.

Lidke DJ and RC Bucknam. 2002. Fault number 566a, Toppenish Ridge structures, Mill Creek fault. In Quaternary Fault and Fold Database of the United States - Version 1.0. Open-File Report 03-417, U.S. Geological Survey, Reston, Virginia. Available at http://qfaults.cr.usgs.gov.

Lidke DJ and RC Bucknam. 2003. Fault number 566b, Toppenish Ridge structures, folds and other faults of the Toppenish Ridge uplift. In Quaternary Fault and Fold Database of the United States Version 1.0. Open-File Report 03-417, U.S. Geological Survey, Reston, Virginia. Available at http://qfaults.cr.usgs.gov.

Lidke DJ, SY Johnson, PA McCrory, SF Personius, AR Nelson, RL Dart, L-A Bradley, KM Haller, and MN Machette. 2003. Map and Data for Quaternary Faults and Folds in Washington State. Open-File Report 03-428, U.S. Geological Survey, Reston, Virginia. Available at http://pubs.usgs.gov/of/2003/428.

Ludwin RS, CS Weaver, and RS Crosson. 1991. Seismicity of Washington and Oregon. In Neotectonics of North America, DB Slemmons, ER Engdahl, MD Zoback, and DD Blackwell (eds). Decade Map 1:77-98, Geological Society of America, Boulder, Colorado.

Mann GM and CE Meyer. 1993. Late Cenozoic structure and correlations to seismicity along the Olympic-Wallowa Lineament, northwest United States. Geological Society of America Bulletin 105:853-871.

McCaffrey R. 2001. GPS Velocity Field and Hazards Assessment for the Pacific Northwest. Collaborative research with Rensselaer Polytechnic Institute, University of Washington, and U.S. Geological Survey. Report 01HQ-GR-0026. Available at http://ees2.geo.rpi.edu/rob/www/ gps/g0026.html. 
McCaffrey R. 2002. Crustal block rotations and plate coupling. In Plate Boundary Zones, Geodynamic Series 30, S Stein and J Freymueller (eds), pp. 101-122. American Geophysics Union, Washington, D.C.

McQuarrie N. 1993. Structural analysis of the Wallula Gap Fault, southeastern Washington. Abstracts with Programs 25:119, Geological Society of America, Boulder, Colorado.

Meghraoui M, R Jaegy, K Lammali, and F Albarede. 1988. Late Holocene earthquake sequences on the El Asnam (Algeria) thrust fault. Earth and Planetary Science Letters 90:187-203.

Miller MM, DJ Johnson, CM Rubin, H Dragert, K Wang, A Qamar, and C Goldfinger. 2001. GPSdetermination of along-strike variation in Cascadia margin kinematics: Implications for relative plate motion, subduction zone coupling, and permanent deformation. Tectonics 20:161-176.

Miller MM and DJ Johnson. 2002. Fate of the Eastern California shear zone along the Cascadia margin and entrainment of the Cascadia fore-arc in oblique subduction. Abstracts with Programs 34:A 106, Geological Society of America, Boulder, Colorado.

Miner A. 2002a. Seismicity and structure of the Columbia Basin: preliminary correlations. Abstracts with Programs, Cordillaren Section 98th Annual Meeting, Geological Society of America, Boulder, Colorado.

Miner A. 2002b. Eocene Tectonics and Active Deformation in Cascadia. MS thesis, Central Washington University, Ellensburg.

Ni JF and M Barazangi. 1986. Seismotectonics of the Zagros continental collision zone and a comparison with the Himalayas. Journal of Geophysical Research 91:8205-8218.

Ning Z and A Qamar. 2003. Seismicity and horizontal strain rate in the Pacific Northwest. Abstracts with Programs 35:582, Geological Society of America, Boulder, Colorado.

Personius SF and DJ Lidke. 2003a. Fault number 565, Rattlesnake Hills structures. In Quaternary Fault and Fold Database of the United States - Version 1.0. Open-File Report 03-417, U.S. Geological Survey, Reston, Virginia. Available at http://qfaults.cr.usgs.gov.

Personius SF and DJ Lidke. 2003b. Fault number 567, Horse Heaven Hills structures. In Quaternary Fault and Fold Database of the United States - Version 1.0. Open-File Report 03-417, U.S. Geological Survey, Reston, Virginia. Available at http://qfaults.cr.usgs.gov.

Personius SF and DJ Lidke. 2003c. Fault number 579, Luna Butte fault. In Quaternary Fault and Fold Database of the United States - Version 1.0. Open-File Report 03-417, U.S. Geological Survey, Reston, Virginia. Available at http://qfaults.cr.usgs.gov.

Personius SF and DJ Lidke. 2003d. Fault number 847, Arlington-Shutler Butte fault. In Quaternary Fault and Fold Database of the United States - Version 1.0. Open-File Report 03-417, U.S. Geological Survey, Reston, Virginia. Available at http://qfaults.cr.usgs.gov.

Piety A, RC LaForge, and LL Foley. 1990. Seismic Sources and Maximum Credible Earthquakes for Cold Springs and McKay Dams, Umatilla Project, North-Central Oregon. Seismotectonic Report 90-1, U.S. Bureau of Reclamation, Denver, Colorado. 
Prescott WH and JC Savage. 1984. Crustal Deformation near Hanford, WA. Open-File Report 84-797, U.S. Geological Survey, Reston, Virginia.

Reidel SP. 1984. The Saddle Mountains: the evolution of an anticline in the Yakima Fold Belt. American Journal of Science 284(8):942-978.

Reidel SP and KR Fecht. 1994. Geologic map of the Priest Rapids 1:100,000 quadrangle, Washington. Open File Report 94-13, Washington State Department of Natural Resources, Division of Geology and Earth Resources, Olympia.

Reidel SP, NP Campbell, KR Fecht, and KA Lindsey. 1994. Late Cenozoic structure and stratigraphy of south-central Washington. In Regional Geology of Washington, ES Cheney and R Lasmanis (eds), Washington Division of Geology and Earth Resources Bulletin 80, pp. 159-180. Washington State Department of Natural Resources, Division of Geology and Earth Resources, Olympia.

Reidel SP, KR Fecht, MC Hagood, and TL Tolan. 1989. The geologic evolution of the central Columbia Plateau.In Volcanism and Tectonism in the Columbia River Flood-Basalt Province, SP Reidel and PR Hooper (eds), pp. 247-264. Special Paper 239, Geological Society of America, Boulder, Colorado.

Reidel SP and NP Campbell. 1989. Guide to the structure of the Yakima Fold Belt. In Field Trips for the Geological Society of America Cordilleran and Rocky Mountain Sections Joint Meeting, Spokane, Washington,N Joseph (ed), pp. 275-304. Circular 86 (geologic guidebook for Washington and adjacent areas), Washington State Department of Natural Resources, Division of Geology and Earth Resources, Olympia.

Reidel SP and TL Tolan. 1994. Late Cenozoic structure and correlations to seismicity along the Olympic-Wallowa Lineament, northwestern United States: Discussion. Geological Society of America Bulletin 106:1634-1638.

Repasky TR and NP Campbell. 1998. Earthquake Hazard Study in the Vicinity of Toppenish Basin, South-Central Washington. U.S. Geological Survey, Reston, Virginia.

Rigby JG and KL Othberg. 1979. Reconnaissance Surficial Geologic Mapping of the Late Cenozoic Sediments of the Columbia Basin, Washington. Open-File Report 79-3, Washington Department of Natural Resources, Division of Geology and Earth Resources, Olympia.

Rohay AC and JD Davis. 1983. Contemporary deformation in the Pasco Basin area of the central Columbia Plateau. In Preliminary Interpretation of the Tectonic Stability of the Reference Repository Location, Cold Creek Syncline, JA Caggiano and DW Duncan (eds). RHO-BW-ST-19P, Rockwell Hanford Operations, Richland, Washington.

Rohay A. 2003. Ongoing deformation and state of stress in the Columbia River flood basalts. Abstracts with Programs 35:136, Geological Society of America, Boulder, Colorado.

Sandness GA, CS Kimball, KE Schmeirer, and JW Lindberg. 1982. Report on Geologic Remote Sensing of the Columbia Plateau. PNL-3140, Pacific Northwest Laboratory, Richland, Washington.

Savage JC, M Lisowski, and WH Prescott. 1981. Geodetic measurements in Washington. Journal of Geophysical Research 86:4929-4940. 
Schuster EJ, CW Gulick, SP Reidel, KR Fecht, and S Zurenko. 1997. Geologic map of Washingtonsoutheast quadrant (2 sheets, scale 1:250,000). Geologic Map GM-45, Washington State Department of Natural Resources, Division of Geology and Earth Resources, Olympia.

Shaffer ME and MW West. 1989. Quaternary faulting in the Frenchman Hills anticline, Yakima fold belt, central Columbia Basin, Washington. Abstracts with Programs 21:142, Geological Society of America, Boulder, Colorado.

SSHAC (Senior Seismic Hazard Analysis Committee). 1997. Recommendations for Probabilistic Seismic Hazard Analysis: Guidance on Uncertainty and Use of Experts. NUREG/CR-6372, U.S. Nuclear Regulatory Commission, Washington, D.C.

Tabor RW, RB Waitt, VA Frizzell, Jr., DA Swanson, GR Byerly, and RD Bentley. 1982. Geologic map of the Wenatchee 1:100,000 quadrangle, central Washington. Miscellaneous Investigations Series Map I1311, U.S. Geological Survey, Reston, Virginia.

Tabor RW, VA Frizzell Jr., JA Vance, and CW Naeser. 1984. Ages and stratigraphy of lower and middle Tertiary sedimentary and volcanic rocks of the central Cascades, Washington: Application to the tectonic history of the Straight Creek fault. Geological Society of America Bulletin 95:26-44.

Tabor RW, VA Frizzell Jr., DB Booth, and RB Waitt. 2000. Geologic map of the Snoqualmie Pass $30 \mathrm{x}$ 60 minute quadrangle, Washington (scale 1:100,000). Geologic Investigations Series Map I-2538, U.S. Geological Survey, Reston, Virginia

Tolan TL and SP Reidel. 1989. Structure map of a portion of the Columbia River flood-basalt province (plate, scale 1:500,000). In Volcanism and Tectonism in the Columbia River Flood-Basalt Province, SP Reidel and PR Hooper (eds), Special Paper 239. Geological Society of America, Boulder, Colorado.

Tolan TL. 1982. The Stratigraphic Relationships of the Columbia River Basalt Group in the Lower Columbia River Gorge of Oregon and Washington. M.S. thesis, Portland State University, Portland, Oregon.

Tolan TL and MH Beeson. 1984. Intracanyon flows of the Columbia River Basalt Group in the lower Columbia River Gorge and their relationship to the Troutdale Formation. Geological Society of America Bulletin 95:463-477.

Tolan TL, NP Campbell, and KA Lindsey. 2004. 3D mapping of the Columbia River Basalt Group (CRBG) and the structural geology of the eastern Yakima fold belt (YFB) and the western Palouse slope: new structural features revealed and expanding the eastern limit of the YFB. Abstracts with Programs 36(4):34, Geological Society of America, Boulder, Colorado.

Walsh TJ, MA Korosec, WM Phillips, RL Logan, and HW Schasse. 1987. Geologic map of Washington - southwest quadrant (1:250,000). Geologic Map GM-34, Washington State Department of Natural Resources, Division of Geology and Earth Resources, Olympia.

WPPSS (Washington Public Power Supply System). 1981. Late Cenozoic tectonics of the Pacific Northwest with special reference to the Columbia Plateau. In Washington Public Power Supply System Nuclear Project Number 2, Final Safety Analysis Report, Amendment 18, Appendix 2.5N, pp. 2.5N-12.5N-44. Washington Public Power Supply System, Richland, Washington. 
WPPSS (Washington Public Power Supply System). 1982. Safety Evaluation Report Related to the Operation of WPPS Nuclear Project No. 2, Docket No. 50-397. Washington Public Power Supply System, Richland, Washington.

West MW. 1997. A Continuation of a "Pilot" Study of Quaternary Surface Deformation, Saddle Mountains Anticline, Northern Pasco Basin, Washington. U.S. Geological Survey, Reston, Virginia.

West MW, FX Ashland, AJ Busacca, GW Berger, and ME Shaffer. 1996. Late Quaternary deformation, Saddle Mountains anticline, south-central Washington. Geology 24(12):1123-1126.

West MW, AJ Busacca, GW Berger, ME Shaffer, and FX Ashland. 1994. A “Pilot” Study of Quaternary Surface Deformation, Saddle Mountains Anticline, Northern Pasco Basin, Washington. U.S. Geological Survey, Reston, Virginia.

West MW and ME Shaffer. 1988. Interim Draft Report - Probabilistic and Deterministic Seismotectonic Studies - O'Sullivan Dam and Potholes Reservoir, Washington. U.S. Bureau of Reclamation, Denver, Colorado.

West DO. 1987. The Wenas Valley fault - Holocene normal faulting or gravitational sliding in the Yakima Fold Belt, Columbia Plateau? Abstracts with Programs 19:463, Geological Society of America, Boulder, Colorado.

Wong I, M Hemphill-Haley, M Dober, and R Schapiro. 2002. Probabilistic Seismic Hazard Analyses Bumping Lake, Clear Creek, French Canyon, and Tieton Dams. U.S. Department of the Interior, Bureau of Reclamation, Denver, Colorado.

Yeats RS. 1986. Active faults related to folding. Chapter 4 in Active Tectonics: Impact on Society, Geophysics Study Committee, Geophysics Research Forum, National Research Council, pp. 63-79. The National Academies Press, Washington, D.C.

Yeats RS, K Sieh, and CR Allen. 1997. The Geology of Earthquakes. Oxford University Press, New York. 

Appendix B

\section{Annotated Bibliography}





\section{Appendix B}

\section{Annotated Bibliography}

Relevant published documents are summarized in this appendix, with particular emphasis on any information pertinent to this topical report. The authors of this topical report made no interpretations of the original works. Annotations focus on the authors' observations and interpretations of structural relationships and are primary sources. The documents annotated here are

Bentley et al. 1980

Berberian 1995

Bruhn 1981

Campbell 1988

Cambell 1989

Campbell and Bentley 1981

Cowan 1981

Davis 1977

Jarchow et al. 1994

Johnson 1989

Lacombe et al. 2006

Lutter et al. 1994

Mann and Meyer 1993

Miner 2002

Montgomery 2008

Price and Watkinson 1989

Reidel 1984

Reidel and Tolan 1994

Reidel et al. 2005

Reidel et al. 1994

Reidel et al. 1989

Saltus 1993

Tabor et al. 1984

Watters 1989

Yeats 1986 
Bentley RD, JL Anderson, NP Campbell, and DA Swanson. 1980. Stratigraphy and Structure of the Yakima Indian Reservation, with Emphasis on the Columbia River Basalt Group. U.S. Geological Survey Open-File Report 80-200, 73 pp.

The Horse Heaven and Simcoe Mountains anticlines are part of the same uplift, divided by the Pine Creek syncline. Symmetry of the Simcoe anticline changes across a NW-trending strike-slip fault that is part of the Arlington-Shutler Butte fault. Displacement of the Simcoe anticline is greatest in the west. Most of the uplift is paralleled by complex splayed fault systems, which includes the Milk Ranch and Satus Creek fault systems. Displacement on the Milk Ranch fault decreases to the west. Lineaments are formed by normal cross faults, several of which divide the Simcoe anticline into en echelon segments. Faults and fracture systems also cross the Satus Basin, forming lineaments that occasionally stretch from the Horse Heaven-Simcoe uplift into Toppenish Basin. Toppenish uplift is divided into three segments (Hembre Mountain, Satus Peak, and Peavine) that are themselves be segmented and change geometry at NWtrending cross faults. The Hembre Mountain segment only shows Quaternary deformation in the far west. Late Quaternary surface rupture that is evident for $30 \mathrm{~km}$ starting at the eastern end of the Satus Peak segment and that includes up to 100 individual ruptures is interpreted as tectonic in origin. The Ahtanum Creek fault cuts the Tampico segment of the Ahtanum uplift. Sedge Ridge should be included in the main group of YFB uplifts, and shows what is likely Pliocene tilting in the west.

Berberian M. 1995. Master "Blind” Thrust Faults Hidden Under the Zagros Folds: Active Basement Tectonics and Surface Morphotectonics. Tectonophysics vol. 241, pp. 193-224.

Berberian describes asymmetrical anticlines with frontal faulting to deep blind thrust faults (these are the same folds LaCombe notes as topographic steps). These deep faults are segmented and discontinuous and are displaced by active deep-seated right-lateral transverse faults. They conclude seismic hazard assessment may underestimate the numbers of faults and sizes of earthquakes because these are blind thrusts.

Bruhn RL. 1981. Preliminary Analysis of Deformation in Part of the Yakima Fold Belt, South-Central Washington. Prepared for Washington Public Power Supply System Report, 27 pp.

Bruhn looked at the style of folding and faulting on Umtanum Ridge and Gable Mountain, measuring strain and confirming that Umtanum Ridge is a kink-type fold. Based on his strain calculations from faulting, he estimated possible depths to a décollement surface for 2 different models, although he says a décollement is not required to accommodate the $\sim 10 \mathrm{~km}$ of shortening estimated by Laubscher. The fold detachment model preferred by Laubscher is probably not representative of YFB, calculated décollement depths were unreasonably deep or shallow and required the folds be symmetrical. The fault ramp model is more reasonable and explains the long gentle limb along with a steep limb, but can't account for all the variations in YFB folds.

Campbell NP. 1988. Structural Geology Along the Northwestern Columbia River Basalt Margin, Washington. Washington Division of Geology and Earth Resources Open-File Report 88-5, $108 \mathrm{pp}$.

Detailed mapping of the northwestern margin of the Columbia River Basalt Margin was conducted to determine the effect of pre-basalt structures on the Columbia River Basalt Group and to compare the orientation of pre-basalt and post-basalt folds and faults. This report closely examines the Chiwaukum graben, the Hog Ranch-Naneum Ridge anticline, the splays of the Straight Creek fault system, the Olympic-Wallowa lineament, and the White River-Naches River structural trend and associated features. Only the faults on the southwest boundary of the Chiwaukum graben extend up into deformed basalt and appear to bend and align with the Hog Ranch-Naneum Ridge anticline that was active during CRBG 
emplacement; other pre-basalt faults and folds in this area appear to be unrelated to structures in the basalt. Structures related to the Straight Creek fault zone appear to pass beneath the basalt and may control the orientation of the folds in that area, which coincides with the CLEW. Three faults between Table Mtn and Darland Mtn extend up into the CRBG, all others appear to be unrelated to basalt structures. The White River-Naches River fault zone marks a change in orientation of deformation in the CRBG, with structures to the north trending NW-SE, and those to the south trending E-W or NE-SW, and some faults appear to continue to within a few kilometers of Yakima.

Campbell NP. 1989. Structural and Stratigraphic Interpretation of Rocks Under the Yakima Fold Belt, Columbia Basin, Based on Recent Surface Mapping and Well Data, in Reidel, S.P., and Hooper, P.R., eds., Volcanism and Tectonism in the Columbia River Flood-Basalt Province. Geological Society of America, Special Paper 239, pp. 209-222, Boulder, Colorado.

Folds in the Yakima fold belt (trending E-W) generally differ in orientation from folds in the deeper Jurassic-Miocene basement rocks. Exceptions are the White River-Naches River fault zone and Hog Ranch-Naneum Ridge, which, like the pre-basalt folds and Olympic-Wallowa lineament, trend NW-SE. Hog Ranch-Naneum Ridge crosses YFB anticlinal uplifts without offsetting them, and was active before and during CRBG eruption. The White River-Naches fault zone separates east-northeast-trending YFB folds from northwest-trending YFB folds, demonstrating influence on YFB fold development and the zone's continuation into the basalt. This fault zone occurs at the southern end of the Straight Creek fault, which splays in this location. These splays align with northwest-trending YFB folds, and one splay reaches through the basalt to form the Manastash fault. The Olympic-Wallowa lineament is aligned with structures in the prebasalt bedrock and may have relatively recently deformed the Manastash fault, and Umtanum, Yakima, and Rattlesnake ridges. Folds in the basalts are tighter and more closely spaced in the interior of the YFB and Columbia Basin, becoming more gently dipping toward the margin of this region. Where deeper and shallower folds are parallel, this difference in fold shape at the margin may be due to distribution of shear over many smaller faults that are not easily visible. In the case of folds trending in opposite directions, gentle folds along the margin could be due to a décollement somewhere above the pre-basalt rocks.

Campbell NP and RD Bentley. 1981. Late Quaternary Deformation of the Toppenish Ridge Uplift in South-Central Washington. Geology, vol. 9, pp. 519-524.

Satus Peak, a section of Toppenish Ridge, is the only Yakima fold showing abundant surface ruptures originating in the late Quaternary. Sag pond bottom material on the peak's slope is dated at 500-600 yr, and faults cut through many Quaternary sediments. Mount St. Helens "set S" tephra (13 ka) constrain the lower age date of another set of faults. Quaternary landslide distribution is partially attributed to rupture location. There are three sets of ruptures grouped by location on the peak- the crestal, hinge, and fan sets. The former two are a result of extension, the latter likely due to slip along an older thrust fault and suggesting a décollement. The anticline also contains large displacement faults of an older age.

Cowan DS. 1981. The Origin of the Umtanum Ridge-Gable Mountain Structural Trend and Implications for a Regional Tectonic Model. Puget Sound Power and Light Skagit/Hanford Nuclear Project Preliminary Safety Analysis Report, Appendix 2S. Nuclear Services Inc., Kirkland, Washington.

This appendix is by Darrel Cowan, from the University of Washington, who reviewed data and interpretations on the origin of Umtanum Ridge and Gable Mountain. He concludes there is no evidence for faulting associated with folds to be coupled to the basement rock. He argues that sementation and changing vergences on this and other folds, including Toppenish Ridge, suggest they are not underlain by deep-rooted imbricate thrusts. Rather, reverse faulting is probably the result of concentric folding and is 
limited to fold hinges. Folding in the CRBG is probably accompanied by diffuse deformation in the basement rocks, rather than along discrete structures.

Davis GA. 1977. Tectonic Evolution of the Pacific Northwest: Precambrian to Present. Appendix 2R C, Washington Public Power Supply System Preliminary Safety Analysis Report, Richland, Washington.

Davis provides a summary of the tectonic evolution of the Pacific Northwest, including the Columbia Plateau and the Yakima folds. His conclusions include 1) a temporal and spatial relationship between regional andesitic magmatism and north-south block-faulting (e.g., Chiwaukum graben), 2) CRBG dike swarms lie near contact between Precambrian crust and younger accreted rocks and may indicate a reactivated zone of weakness, 3 ) principal stress is north-south, and least principal stress varies from vertical to east-west with no systematic pattern, and 4) the OWL is a fictional structural element, although limited dextral strain may have occurred along the central third of the lineament between Ellensburg and Wallula Gap.

Jarchow CM, RD Catchings, and WJ Lutter. 1994. Large-Explosive source, Wide-Recording Aperture, Seismic Profiling on the Columbia Plateau, Washington. Geophysics, vol. 59, no. 2, pp. 259-271.

The authors ran a high-resolution seismic line down the length of Hog Ranch Buttes from just north of its intersection with Naneum Ridge to just south of Yakima Ridge. This report discusses using diving waves to isolate the base of basalt and other subsurface layers that are difficult to isolate using normal techniques. There is pronounced changes in thickness of basalt from north to south, shallowing by 0.6 $\mathrm{km}$ across the $15 \mathrm{~km}$ wide Kittitas Basin, and even more pronounced changes in depth to basement, which rises from $8 \mathrm{~km}$ at the south end of the profile to $2 \mathrm{~km}$ at the north end. They conclude that base of basalt highs do not correspond to surface anticlines.

Johnson PA. 1989. Central Washington Seismicity: Evidence for a Reactivated Buried Continental Rift and Northwest-Trending Structural Zones. Geophysical Research Letters, vol. 16, no. 11, pp. $1325-1328$.

Clustering of microseismicity in the Yakima Fold belt varies in geographic distribution between the shallower Columbia River basalt and the deeper basement. Shallow clustering occurs near Chelan, WA, just to the northeast of the Entiat fault. In contrast to other studies which repeatedly indicate north-south compression as the cause for YFB structural development, focal mechanisms of this earthquake cluster suggests northwest-southeast compression. The Corfu seismic belt composes the second shallow cluster, with earthquakes here often occurring in swarms. A west-trending alignment of epicenters in this seismic belt is likely related to the Saddle Mountains fault. Seismic clusters also occur in rock deeper than $10 \mathrm{~km}$. Deep and shallow earthquake hypocenters are influenced by the underlying rift graben. Because of the proximity and dip of the Chiwaukum graben, this rift graben is interpreted to be an extension of the Chiwaukum graben. Additionally, YFB seismicity may be related to the buried continental rift, which could act as a structural control dictating the location of seismic clusters. Rifting may have weakened local crust, increasing the likelihood that stress is relieved along nearby structures. The Straight Creek fault system may also influence the westernmost cluster of seismicity.

Lacombe S, F Mouthereau, S Kargar, and B Meyer. 2006. Late Cenozoic and Modern Stress Fields in the Western Fars (Iran): Implications for the Tectonic and Kinematic Evolution of Central Zagros. Tectonics, vol. 25, p. TC1003. 
The following is a brief summary of the section in their article that is of interest to this topical report. They interpret the Zagros fold-thrust belt to consist of primarily buckle folds without major thrusts based on the symmetry of the folds in shape and wavelength controlled by a décollement within the underlying Hormuz Salt Beds. A topographic step or linear change in elevation is thought to be caused by normal faults in the basement rocks that have been reactivated as high angle reverse faults. These faults have cut across the décollement, but do not break the surface, forming blind thrust faults.

Lutter WJ, RD Catchings, and CM Jarchow. 1994. An Image of the Columbia Plateau from Inversion of High-Resolution Seismic Data. Geophysics, vol. 59, no. 8, pp. 1278-1289.

The authors ran a high-resolution seismic line down the length of Hog Ranch Buttes from just north of its intersection with Naneum Ridge to just south of Yakima Ridge. They detected planar low velocity zones that they believe are thrust faults associated with the anticlinal folds. Their figure $7 \mathrm{~b}$ is a schematic cross section running S-N showing a decollement at the base of the basalt with linear faults dipping 30 degrees from the north-vergent side of the Boylston and Frenchman Hills (Whisky Dick) anticlines down to the decollement. Basalt is thickest in the south near Yakima Ridge, and shallows to the north. They particularly note the rapid shallowing of the basalt base between the Boylston and Frenchman Hill anticlines and the presence of a basement high near the north end of the line.

Mann GM and CE Meyer. 1993. Late Cenozoic Structure and Correlations to Seismicity Along the Olympic-Wallowa Lineament, Northwest United States. Geological Society of America Bulletin, vol. 105, pp. 853-871.

Like other NW-trending fault zones in the NW Cordillera, the Olympic-Wallowa lineament (OWL) is probably a right-slip fault system accommodating eastern basin-and-range extension. A 1936 earthquake of magnitude 6.1 occurred in the Wallula fault zone (WFZ), the section of the OWL passing through the Columbia Plateau. The WFZ is a right-slip extensional duplex. Surface features in several areas throughout the OWL are a result of basement right-slip fault zones: for instance, 'disrupted zone' fault segments in the Long Valley fault system. The OWL experiences an abrupt change in structural style when crossing a crustal boundary at Wallula Gap, perhaps due to a change in basalt thickness. Like this crustal boundary, the Kennewick lineament possesses a magnetic anomaly. Holocene faulting may be recorded in Kennewick lineament sediments and appear to branch out from this structure. Earthquake hypocenters (2-5 km deep) and anticlinal structure west of Wallula Gap suggest a progressive crustal detachment in the area. Because the WFZ is historically active and the Rattlesnake-Wallula alignment (RAW) runs parallel to the WFZ, it is likely that the RAW is also active.

Miner AM. 2002. Eocene Tectonics and Active Deformation in Cascadia. MS Thesis, Central Washington University, Ellensburg, Washington, 101 pp.

There are two parts to this thesis; this description is for the second that deals with subsurface structure of the Columbia Basin based on seismicity. Seismicity delineates planes associated with axial surfaces of the folds at depth. High angle faults at depth initially controlled faulting in the basalts but were later truncated by a décollement between 5 and $10 \mathrm{~km}$ deep in the central part of the Columbia Plateau. A similar décollement may also occur further west but is more difficult to identify from the available seismicity data. Faults below the décollement are still active, but are no longer directly linked to faults near the surface. Near the Ice Harbor dikes, strike-slip solutions for earthquakes suggests that area is coupled to the basement.

Montgomery SL. 2008. New Exploration Concepts Highlight Columbia River Basin's Potential. Oil and Gas Journal, vol. 106, no. 2, pp. 35-42. 
Montgomery summarizes the ideas and information on the geology of the Columbia Basin that make prospects for oil or gas finds still feasible. The information he presents he's been able to glean from publically available data and hints of proprietary oil and gas company data. Those companies have been creating an enhanced model of the sub-basalt geology using well and outcrop data as well as gravity, magnetic, seismic reflection and seismic refraction data. Three types of structures dominate: "horst-like basement uplifts; a system of NW-SE dextral, oblique-slip faults: and a set of east-west folds commonly bounded by low-displacement thrusts....In some areas, thrusts are detached, while in others they may be rooted in older, basement faults. In general, it is now speculated that much of the basalt cover responded as a separate structural entity relative to the underlying sedimentary section. New analysis of seismic and other data suggests that ramp-type geometries are prevalent in certain parts of the basin."

Price EH and AJ Watkinson. 1989. Structural Geometry and Strain Distribution Within Eastern Umtanum Fold Ridge, South-central Washington, in Volcanism and Tectonism in the Columbia River Flood-Basalt Province, Geological Society of America, Special Paper 239, pp. 283-292.

Detailed mapping of strain distribution and the structural geometry of Umtanum Ridge led the authors to conclude that the anticline formed as an asymmetric kink-fold with predominantly flexural strains in the steep northern limb. The large reverse fault along the northern limb is conjectured to have formed from the kink-fold at depth, and is not thought to be deep-seated. There does not appear to have been significant strike-slip motion along the fault.

Reidel SP. 1984. The Saddle Mountains: The Evolution of an Anticline in the Yakima Fold Belt. American Journal of Science, vol. 284, pp. 942-978.

The Saddle Mountains is an anticlinal ridge that can be divided into six segments based on fold geometry. A high-angle reverse or thrust fault, the Saddle mountains fault, has caused displacement of at least 2.5 $\mathrm{km}$ along the ridge. Secondary tectonic structures are present on the Saddle Mountains. The Smyrna anticline and Hog Ranch-Naneum Ridge anticline extend beyond the anticlinal uplift. Local thrust faults occur near Saddle Gap and are common west of Sentinel Gap. Distinct fault zones are present on the Saddle Mountains, which are also modified by a northwest-trending shear system. Uplift rate has slowed since the early Miocene. Frequent, low-magnitude displacements during continuous deformation are indicated by lack of fault scarps and presence of folded basalts and sediments. Different areas of the Saddle mountains fault show deformation of different ages. Uplift probably occurred in stages, marked by changes in growth rate. Because other YFB anticlinal folds indicate similar ages and rates of growth, the Saddle Mountains can act as a model for these other folds. This model is consistent with the known Columbia Plateau tectonic context. Furthermore, similarity between age and supply of the Columbia River Basalt Group and the growth rate of the Saddle Mountains indicates that the YFB and CRBG are caused by the same tectonic processes. Shallow earthquake swarms in the area indicate persisting growth. Segments of the Saddle Mountains may be partially controlled by basement structures and reactivation of basement faults, and the Hog Ranch-Naneum Ridge anticline is directly connected to basement structures.

Reidel SP and TL Tolan. 1994. Late Cenozoic Structure and Correlations to Seismicity Along the Olympic-Wallowa Lineament, Northwestern United States: Discussion. Geological Society of America Bulletin, vol. 106, pp. 1634-1638.

Mann GM. 1994. Late Cenozoic Structure and Correlations to Seismicity Along the Olympic-Wallowa Lineament, Northwestern United States: Reply. Geological Society of America Bulletin, vol. 106, pp. 1639-1641.

This is a discussion of the Mann and Meyers (1993) paper followed by Mann's response to the Reidel and Tolan comments. Reidel and Tolan argue that the OWL is not a single, continuous structure. The Mann 
and Meyers duplex model of the Wallula fault zone is incorrect; the fault zone has little or no strike-slip movement, and dikes occurring on either side of the Wallula fault zone near the Blue Mountains indicate movement on the fault zone occurred at least $8.5 \mathrm{Ma}$. Reidel and Tolan also argue that magnetic anomalies surrounding the Kennewick-Cold Creek lineament are a result of basalt-cored anticlines, and the lineament is a break in slope from flood terraces.

Reidel SP, J Bush, D Garwood, J Kauffman, and BS Martin. 2005. The Tectonic Evolution of the Northern Columbia River Flood-basalt Province. Geological Society of America Abstracts with Programs, vol. 37, no. 7, p. 126.

Subsidence during basalt eruption formed basins at the boundary of the continental craton and accreted terrains. In the YFB, fold growth, subsidence, basalt eruption, and pole rotation have closely correlated rates.

Reidel SP, NP Campbell, KR Fecht, and KA Lindsey. 1994. Late Cenozoic Structure and Stratigraphy of South-central Washington. Washington Division of Geology and Earth Resources Bulletin, vol. 80, pp. 159-180.

The OWL is parallel to but not connected to basement structures, and causes change in ridge trends from Manastash Ridge to Rattlesnake Mountain. In general, the trends of anticlines reflect the trends of the areas they cross. Folds in the YFB are north-verging with the exception of some anticlines including Columbia Hills, Cleman Mountain, and other anticlinal segments, which are south-verging. The boundary between Saddle Mountains segments Eagle Lake and Saddle Gap occurs above the suture zone between the continental craton and accreted terranes. The Hog-Ranch-Naneum Ridge anticline may not, as was previously thought, be connected to the basement. In the YFB, evidence for continued displacement is generally only present in frontal fault zones. Quaternary faulting appears equally distributed in CLEW and non-CLEW regions, and fold belt development has likely been evenly distributed since the Miocene. Although stresses are evenly distributed, seismicity is concentrated in the YFB's competent synclines, for movement in the incompetent anticlines can occur aseismically. The Saddle Mountains fault is the only YFB fault known to be associated with seismicity.

Reidel SP, KR Fecht, MC Hagood, and TL Tolan. 1989. The Geologic Evolution of the Central Columbia Plateau, in Reidel, S.P., and Hooper, P.R., eds., Volcanism and Tectonism in the Columbia River Flood-Basalt Province. Geological Society of America, Special Paper 239, pp. 247-264, Boulder, Colorado.

Ridges in the eastern and central portion of the YFB are more closely spaced than ridges to the west, and ridges within the CLEW are the most closely spaced. Anticlinal trends- such as those of the Yakima and Umtanum Ridges- change direction when crossing the CLEW, and the Yakima Ridge decreases in structural relief in this area. For most frontal faults in the YFB, as anticlinal structural relief decreases, the fault itself dies out. Because crustal shortening in the YFB is small, the CRBG is more likely connected via local or limited décollements than via a regional décollement.

Saltus RW. 1993. Upper-Crustal Structure Beneath the Columbia River Basalt Group, Washington: Gravity Interpretation Controlled by Borehole and Seismic Studies. Geological Society of America Bulletin, vol. 105, pp. 1247-1259.

Saltus developed a 3-D gravity model that used deep boreholes and seismic studies to help constrain subbasalt crustal structure in the northern part of the Columbia Basin. The model indicates that sub-basalt sedimentary rocks are thickest (up to $5 \mathrm{~km}$ thick) beneath the Yakima Basin, that the Chiwaukum graben does not continue beneath the CRBG, and that sub-basalt sediments are probably not thrust into the cores 
of the Yakima Fold Belt basalt anticlines. A north-south gravity high is crossed but not offset by the Olympic-Wallowa lineament, which is also expressed in the gravity field. The gravity high may be due to a basement high overlain by a much thinner sub-basalt sediment sequence, or it could be due to a highdensity structure in the basement, possibly related to a failed continental rift.

Tabor RW, VA Frizzell Jr., JA Vance, and CW Naeser. 1984. Ages and Stratigraphy of Lower and Middle Tertiary Sedimentary and Volcanic Rocks of the Central Cascades, Washington: Application to the Tectonic History of the Straight Creek Fault. Geological Society of America Bulletin, vol. 95, pp. 26-44.

Sediment deposition since the Eocene in three horst blocks along the western margin of the CRBG document primarily vertical movement along the Straight Creek fault and its southeasterly trending splays. Movement on the fault appears to have decreased during the Oligocene and ceased by Miocene time, although structures aligned with the OWL appear to have influenced folding of the CRBG.

Watters TR. 1989. Periodically spaced anticlines of the Columbia Plateau, in Reidel, S.P., and Hooper, P.R., eds., Volcanism and Tectonism in the Columbia River Flood-Basalt Province. Geological Society of America, Special Paper 239, pp. 283-292, Boulder, Colorado.

Regularly spaced anticlinal ridges of the YFB can be divided into three domains based on ridge spacing and orientation. These include a) the northern domain, which is composed of eastern Umtanum Ridge, Saddle Mountains, and Frenchman Hills, b) the central domain with Rattlesnake, Yakima Ridge, western Umtanum Ridge, Cleman Mountain, eastern Horse Heaven Hills, Bethel Ridge, and Manastash Ridge, and finally c) the southern domain with Gordon Ridge, Columbia Hills, Toppenish Ridge, Ahtanum Ridge, and western Horse Heaven Hills. Mean anticline orientation in the northern domain it N79. $8^{\circ} \mathrm{W}$, with mean spacing between anticlines $19.6 \mathrm{~km}$. The central and southern domain ridges have mean orientations of $\mathrm{N}^{\circ} 1^{\circ} \mathrm{W}$ and $\mathrm{N} 79.1^{\circ} \mathrm{E}$, and mean spacings of $11.6 \mathrm{~km}$ and $27.6 \mathrm{~km}$, respectively. The CLEW structures running through the central domain demonstrate greater folding, may be due to connection to basement structures. Movement within the basalts is analogous to thin elastic plates (the basalts) moving along low friction contacts (sedimentary interbeds).

Yeats RS. 1986. Active faults related to folding. Chapter 4 in Active Tectonics: Impact on Society, Geophysics Study Committee, Geophysics Research Forum, National Research Council, pp. 6379. The National Academies Press, Washington, D.C.

All fold-and-thrust belts have an underlying décollement that slopes toward an adjacent mountain belt interior. The fold belts themselves have a wedge-shaped cross-section which tapers toward the mountain belt. Movement above the décollement takes place under pure friction sliding. Flexural-slip folding is universal to foreland fold-and-thrust belts and results in both flexural-slip and bending-moment faults. Toppenish Ridge displays bending-moment faults. In this location, the hinge of an overturned syncline has thrust faults that are here interpreted as bending-moment faults as opposed to Campbell \& Bentley's (1981) interpretation that it is the surface expression of the Mill Creek décollement thrust. Thrust faults in a décollement can advance and new thrusts may form and propagate faster than regional plate convergence rates. Also, it is possible for thrust belts to accommodate most tectonic stresses in the region closest to a convergence zone, as opposed to stresses being equally distributed over the thrust belt. If a fold relatively close to a stress source is being displaced, more distal folds may be protected and become stable. Because folds move towards a fold belt's edge, that area is more likely to have actively growing folds with surface ruptures. A lack of visible displacement does not preclude active faulting, as very young faults may not have large enough displacement to be noticeable. Earthquake magnitude in a foldand-thrust belt depends partially on composition of the décollement zone; if the zone deforms plastically, 
magnitudes are likely to be much smaller than if the zone is thick and deforms by Coulomb friction. In the latter case, larger earthquakes could occur in the thicker region of the tapered wedge décollement. 




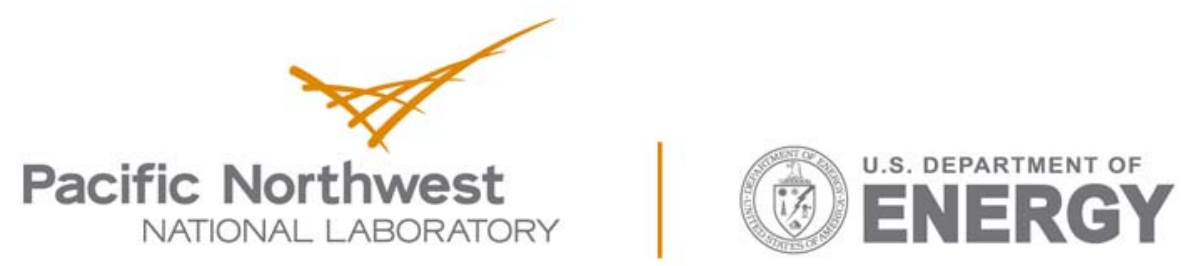

Proudly Operated by Battelle Since 1965

902 Battelle Boulevard

P.O. Box 999

Richland, WA 99352

1-888-375-PNNL (7665)

www.pnnl.gov 